\title{
15. THE LORD HOWE RISE RHYOLITES
}

\author{
Gerrit J. van der Lingen, Sedimentation Laboratory, New Zealand Geological Survey, Christchurch, New Zealand
}

\begin{abstract}
During Leg 21 of the Deep Sea Drilling Project, a hole was drilled in the southern Lord Howe Rise, northwest of New Zealand (Site 207). The lower 156 meters were in rhyolite volcanics. These volcanic rocks can be subdivided into two units (Units 4 and 5 of the total drilled sequence).

The upper unit consists of pumiceous lapilli tuffs and rhyolite flows. The latter are mainly fragmental. Both lithologies are heterolithologic. Though some parts of the flow rocks superficially resemble ignimbrites, they are considered to be normal rhyolitic flows that are in part autobrecciated. The lapilli tuffs are the result of explosive eruptions.

The lower unit consists of monolithologic vitrophyric rhyolite flows, autobrecciated in part. The rocks underwent devitrification and/or argillization to a far greater degree than those in the upper unit.

Criteria for determining either subaerial or subaqueous extrusion are difficult to establish for the flow rocks. The lapilli tuffs in the upper unit probably were extruded subaerially or at very shallow depth.

Radiometric dating of rocks from the upper unit provided Upper Cretaceous ages.
\end{abstract}

\section{INTRODUCTION}

The lower part of Hole 207A, on the southern Lord Howe Rise, penetrated acid volcanics from 357.28 to 513.00 meters subbottom depth (see Part I). Drilling had to be abandoned because of mechanical difficulties. Though no cores or core catcher samples were recovered from the last 18 meters, it is presumed that the base of the volcanics was not reached.

Core recovery through the volcanics was 32.27 meters, or 20.72 percent. Recovery is divided irregularly over the drilled interval (see Figure 1). The best recovery is from Core 45 to Core 48 .

Criteria for the mode of emplacement of volcanics are in part based on vertical and lateral field relations. Both the discontinuous core recovery and the limited diameter of the cores therefore limit the number of criteria available for determining the mode of emplacement of the Lord Howe Rise rhyolites.

The present chapter is based only on shipboard visual core descriptions and on postcruise work on samples taken on board the ship.

The volcanic sequence can conveniently be divided into two units, Units 4 and 5 of the total drilled sequence (see Site 207 report). The boundary between them is in Core 42, Section 1, at $105 \mathrm{~cm}$. Differences between the two units are not fundamental. Both certainly belong to the same eruptive sequence. Both units contain abundant fragmental vitrophyric rocks. Unit 4, however, is heterolithologic and locally contains pumice fragments. Unit 5 is monolithologic and does not contain pumice fragments. Rocks of Unit 5 are also more devitrified and argillized than those of Unit 4. Rocks in both units contain phenocrysts of quartz and plagioclase (oligoclase-andesine). Potassium feldspar (sanidine) is found only sporadically in
Unit 4 and is absent in Unit 5. No phenocrysts of ferromagnesian minerals were observed, though some pseudomorphs after possible ferromagnesian minerals are present.

Being vitrophyric rocks, exact petrographic classification is not easy. Devitrification and argillization make whole-rock chemical analysis a less reliable approach. The refractive index of the glass in both units varies from 1.500 to 1.502 . This, together with the phenocryst mineralogy, places these rocks in the rhyolite-rhyodacite class. For convenience the rocks will be called rhyolites. Size terms used in this paper are those proposed by Fisher (1966) and consist of ash, $(<2 \mathrm{~mm})$, lapilli, $(2-64 \mathrm{~mm})$, and blocks and bombs $(>64 \mathrm{~mm})$.

\section{UNIT 4}

Core recovery in Unit 4 was only 10.8 percent, with appreciable gaps between cores (Figure 1). This unit contains fragmental rocks of varied appearance. In the core descriptions (Part I), two principal names have been used for rocks of this unit, lapilli tuff and fragmented vitrophyric rhyolite. The latter has been used as a nongenetic term for those rocks whose mode of emplacement is uncertain.

Lapilli tuffs occur at the base of Core 34 (Figure 2) and from the top of Core 39 to the base of Unit 4 in Core 42 (Figures 3 and 4). Most of them are heterolithologic. The predominant lapilli lithology is pumice (Figures 5 and 6), with minor lithic (Figures 7 and 8), vitrophyric (Figures 3 and 4), and granophyre (Figure 9) fragments. The pumice is either cellular (Figures 5 and 10) or fibrous (Figure 6). Locally they contain quartz phenocrysts. The vitrophyric 


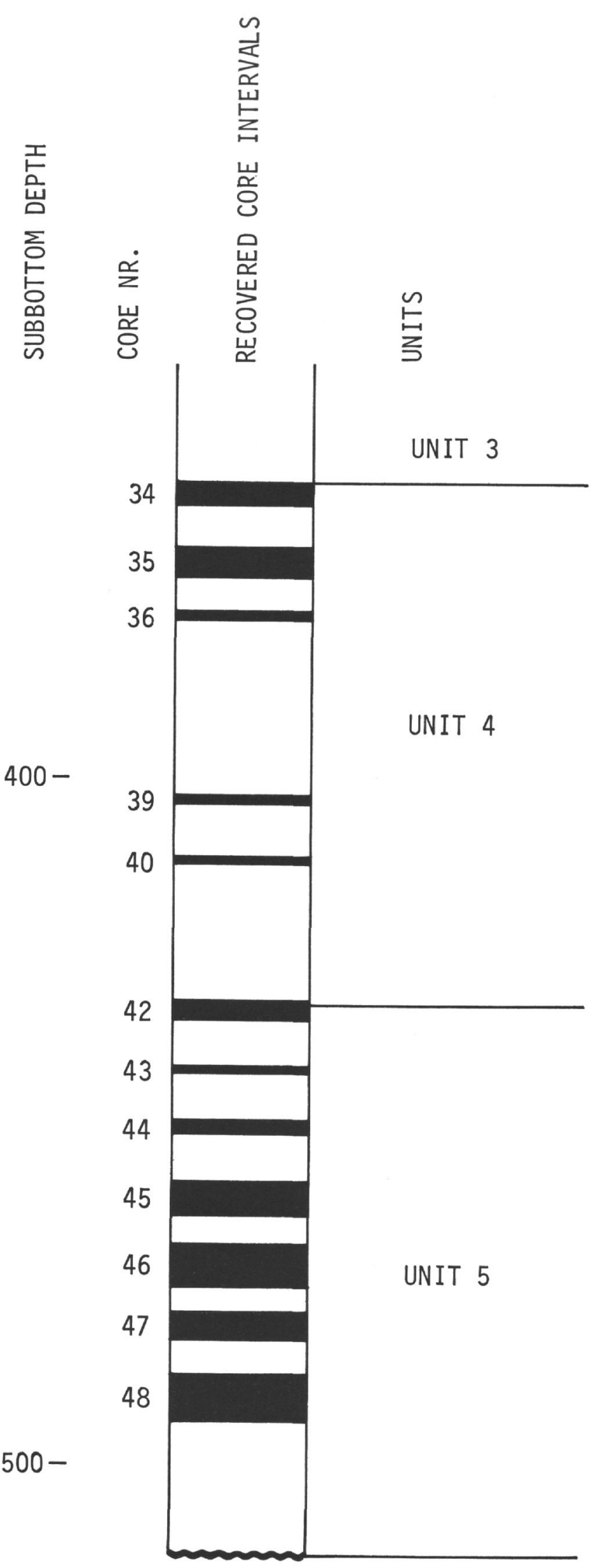

Figure 1. Distribution of recovered core intervals of the Lord Howe Rise rhyolites in Hole 207A.
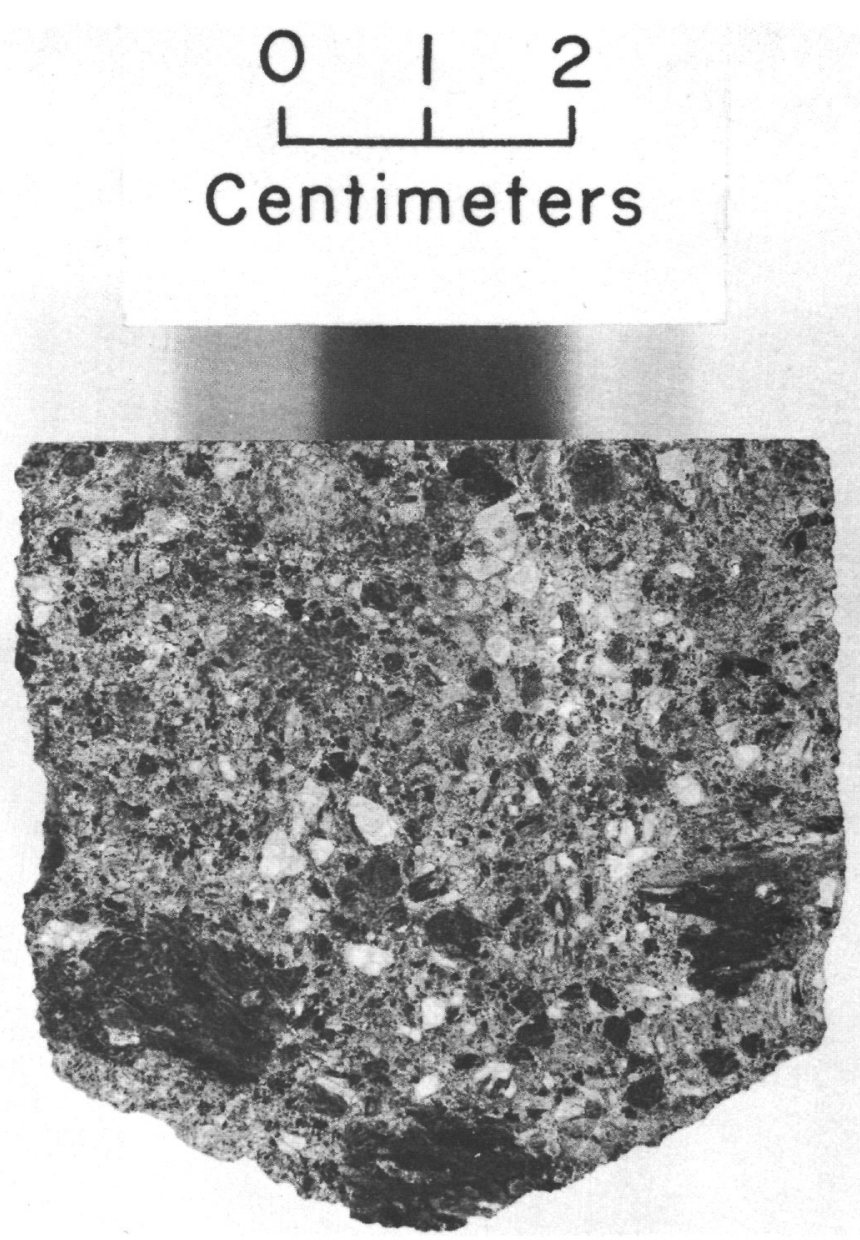

Figure 2. Sample 34 (CC). Pumiceous lapilli tuff. The dark fragments are vitrophyric rhyolite.

rhyolite (accessory) fragments consist mainly of black to brown unaltered perlitic glass with quartz and feldspar phenocrysts. Rare fragments of spherulitic vitrophyric rhyolite, typical of Unit 5, have also been observed. Lithic fragments are mainly lithoidal rhyolite (Figure 8) and felsite (Figure 7). One fragment in the sample of Figure 2 shows a devitrification texture known as snowflake texture (Figure 11; Anderson, 1969). The "snowflakes" are single poikilitic quartz crystals, as shown by the uniform extinction of the quartz framework (Figure 13). Some "snowflakes" show faint idiomorphic outlines (Figure 12). Locally, the quartz has grown into larger, irregular patches (Figure 14). Anderson suggests that the snowflake texture might be restricted to ash-flow tuffs, but he admits that this is only a tentative hypothesis. Similar textures were also produced experimentally in natural rhyolitic glass by Lofgren (1971). He calls the texture micropoikilitic and the patches "micropoikilitic quartz crystals." The ash fraction contains rock fragments of similar lithology mixed with crystals and crystal fragments of quartz and feldspars (Figure 7). The fragments are angular to subrounded. Locally, they show crude stratification and some size sorting (Figure 4).

All these characteristics suggest that these rocks are air-fall pyroclastics, derived from explosive eruptions (see Ross and Smith, 1961, p. 19; Ewart, 1963). 


\section{$\begin{array}{lll}0 & 1 \\ 1 & 1\end{array}$ \\ Centimeters}

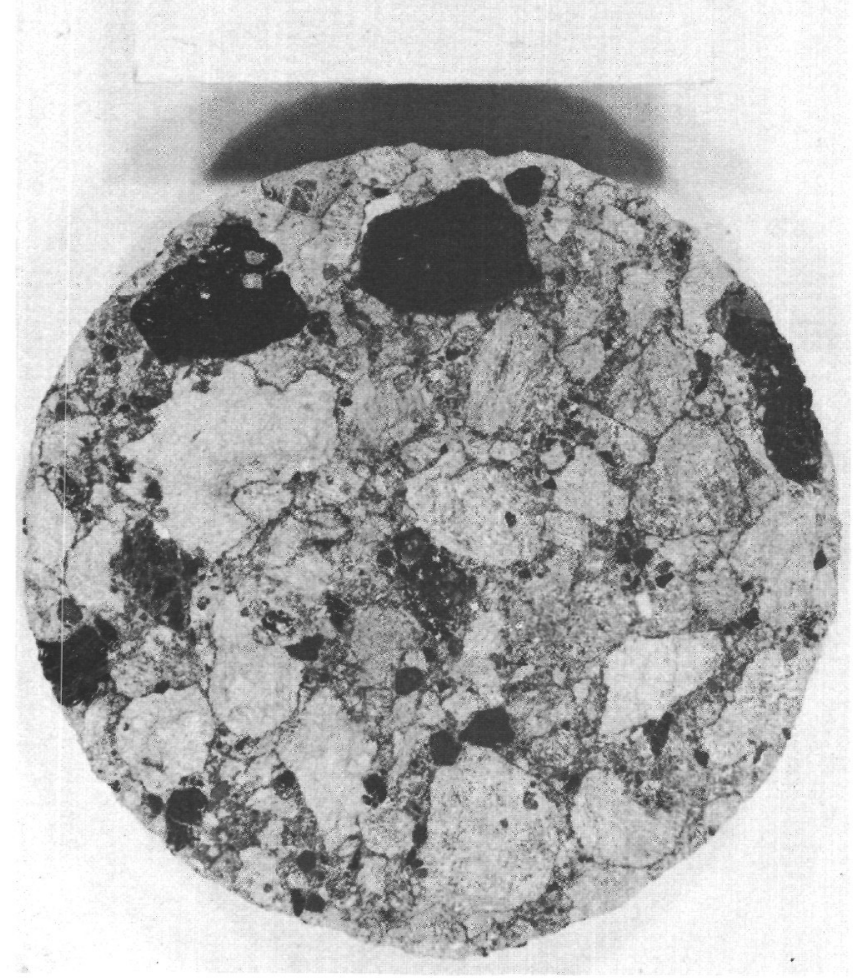

Figure 3. Sample 39-1(143-144). Pumiceous lapilli tuff. Dark fragments are vitrophyric rhyolite. Note phenocrysts in some of the fragments.

The rest of Unit 4 consists of vitrophyric rhyolite, fragmented to various degrees. Fluidal banding is locally present. Perlitic texture is common. Colors vary greatly, but black and dark brown predominate, locally giving the rock a pitchstone appearance. These rocks somewhat resemble those of Unit 5. The difference is mainly in the presence of potassium feldspar and sporadic accessory fragments (mainly pumice and lithic fragments). The glassy groundmass is also far less devitrified or argillized than in Unit 5 .

Near the base of Core 35, the rock contains pumice fragments which are lensoid and elongated in a parallel fashion (Figure 15). This resembles the texture of a lenticulite, well known from ash-flow tuff (ignimbrite) deposits (Steiner, 1960, figure 6; Ross and Smith, 1961, figure 1; Ewart, 1965, figure 3). The lenticles in a lenticulite are collapsed pumice fragments, which in hand specimen look black, in a lighter colored groundmass. In the sample from Core 35, however, the groundmass is dark and the lenticles are light colored. This difference need not be fundamental. There may be transitional stages in the collapse of pumice fragments.

To determine if this part of Core 35 is an ash-flow tuff, other diagnostic features have to be looked for. As already

\section{$\begin{array}{lll}0 & 1 \\ 1 & 1\end{array}$ \\ Centimeters}

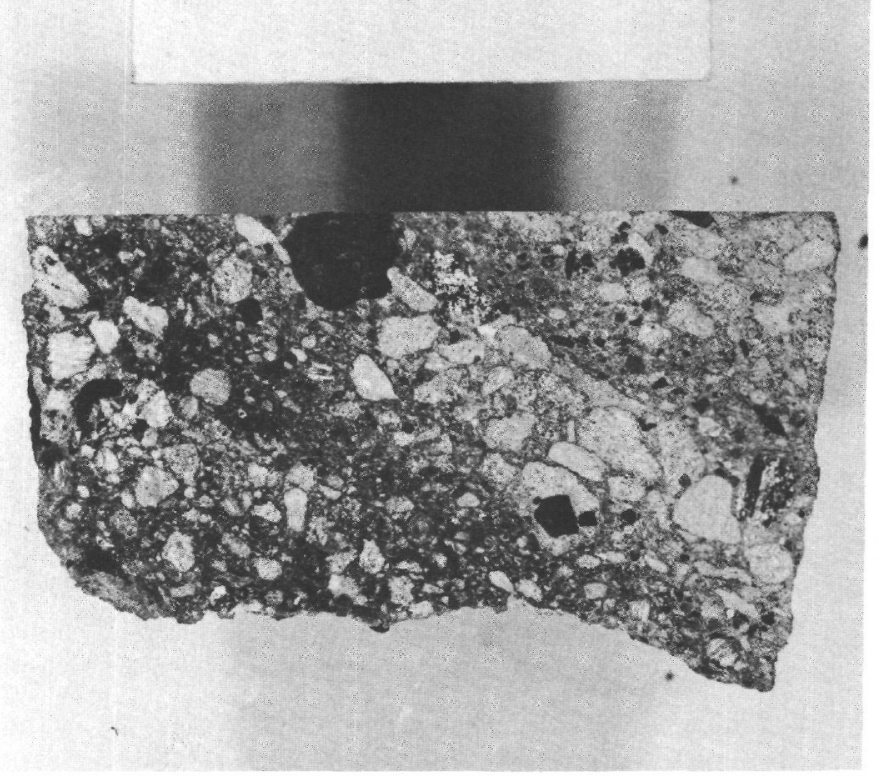

Figure 4. Sample 39 (CC). Pumiceous lapilli tuff, showing crude stratification and sorting.

stated in the introduction, the absence of data on field relations limits the possibilities for final answers on modes of emplacements, so that we have to resort to microscopic criteria. The most important diagnostic feature for ash-flow tuffs is the presence of glass shards in the groundmass (vitroclastic texture), more or less welded together (Ross and Smith, 1961) or cemented by mesostasis (Steiner, 1960). Supporting features are devitrification and vaporphase crystallization (Ross and Smith, 1961). Glass shards may have been drawn out during flow, but the vitroclastic texture is generally still recognizable in the discontinuity of the "flow lines" (Steiner, 1960, p. 15; Ross and Smith, 1961, p. 25 and 34).

A thin section from the sample of Figure 16 shows pumice fragments (Figur es 17 and 18), accessory fragments (Figure 17), and phenocrysts (Figures 19 and 20) in a perlitic glassy groundmass. The flow lines in the groundmass are generally continuous (Figure 19), but this is not always unambiguous. However, obvious glass shards were not observed. The flow lines are deflected by phenocrysts (Figure 19) and conform to deep embayments in phenocrysts (Figure 20). Pumice fragments are generally fibrous, with the "fibers" sharply abutting against the groundmass (Figure 17). They may show plastic deformation. Pumice fragments may also depict a "granular" or crinkly texture. The flow lines in the groundmass can be intricately folded (Figure 21), suggesting shear during the final stages of flow. It is not always easy to distinguish between pumice fragments and groundmass in thin section. Devitrification has only taken place to a minor degree, 


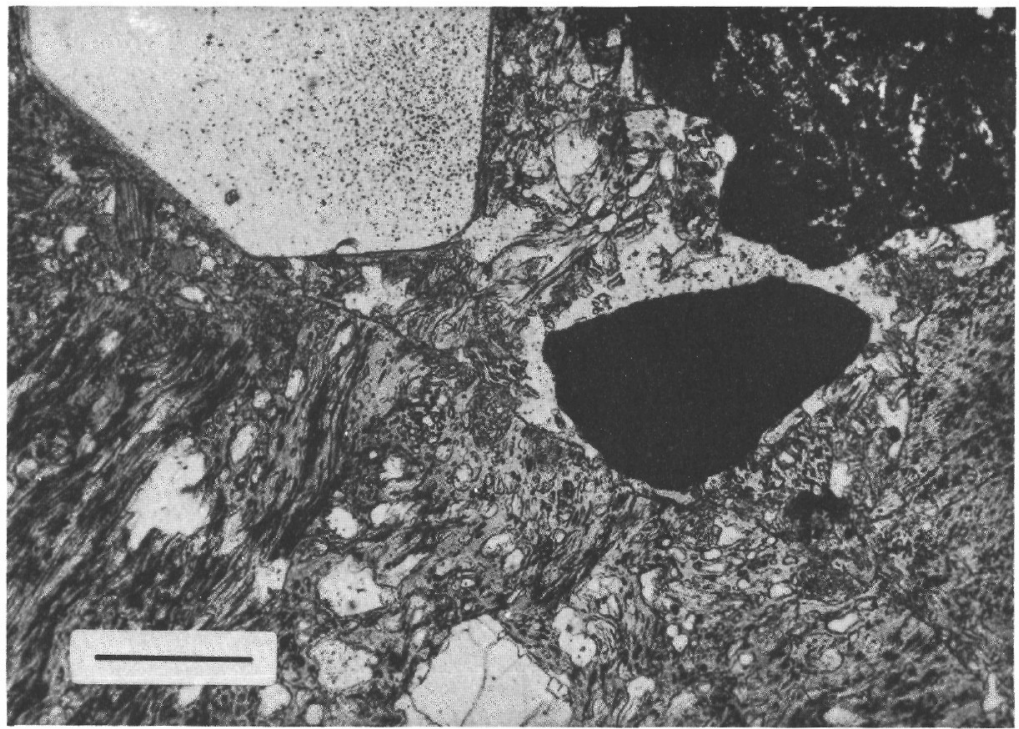

Figure 5. Photomicrograph of Sample 34 (CC). Pumiceous lapilli tuff. Cellular and fibrous pumice fragments with phenocrysts, opaque grains, and rock fragments. Plane polarized light. Length of scale bar is $500 \mu$.

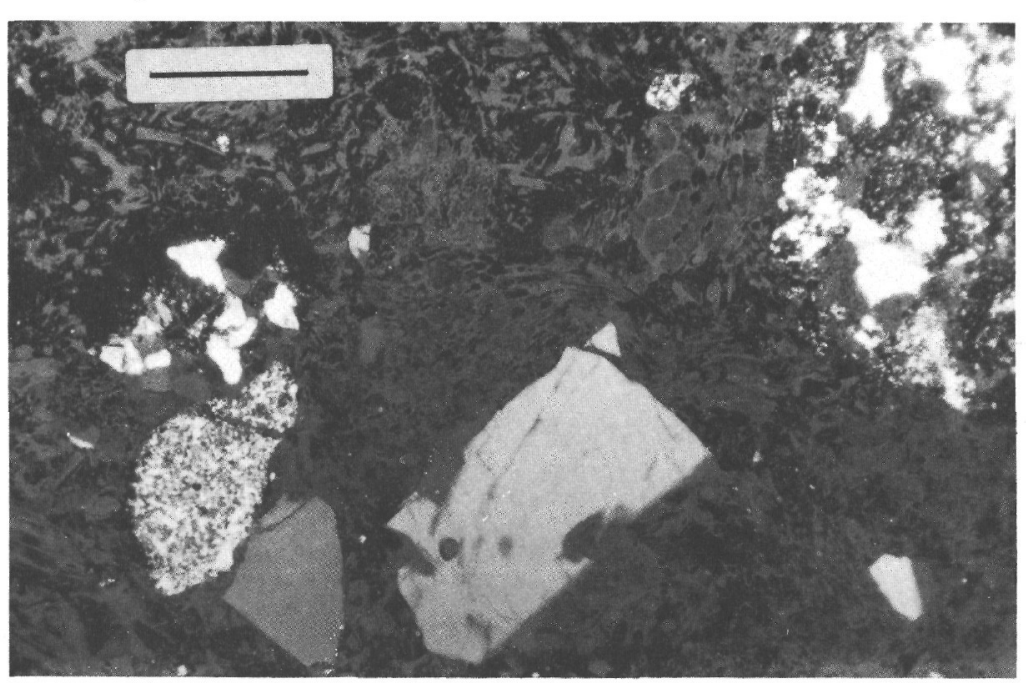

Figure 7. Photomicrograph of Sample 39 (CC). Pumiceous lapilli tuff. Pumice fragments, lithic fragments, and phenocrysts (quartz and feldspar). Partly crossed polarizers. Length of scale bar is $500 \mu$.

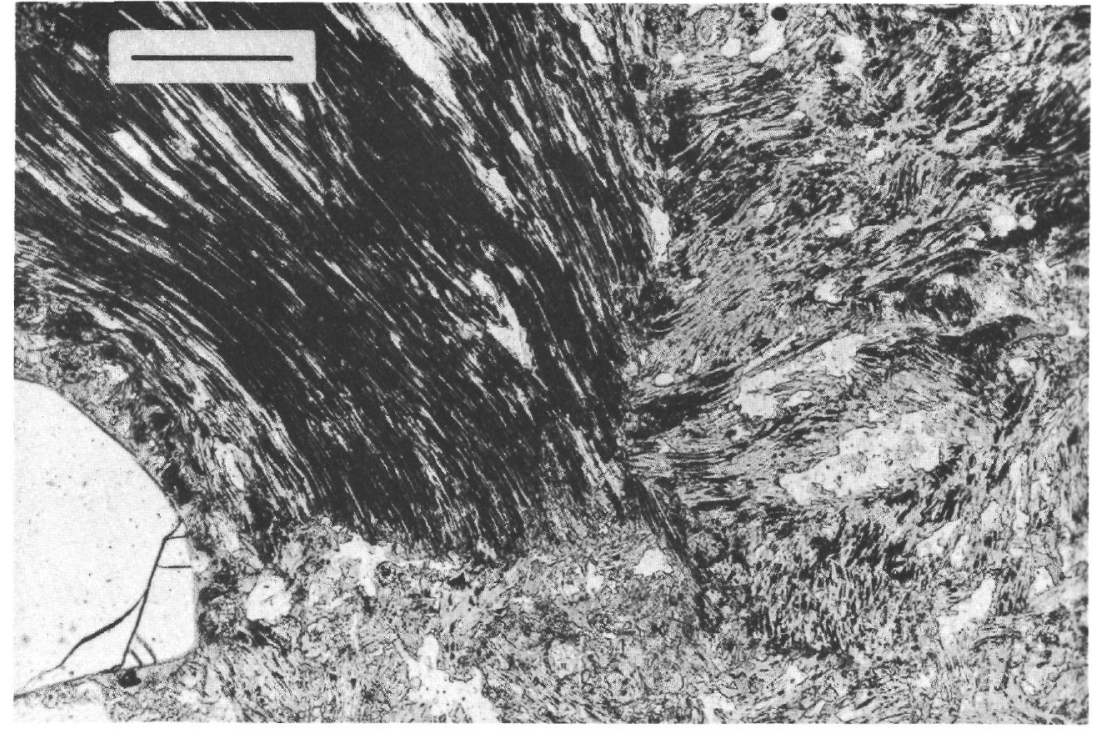

Figure 6. Photomicrography of Sample 34 (CC). Pumiceous lapilli tuff. Fibrous pumice fragments and quartz phenocrysts. Plane polarized light. Length of scale bar is $500 \mu$.

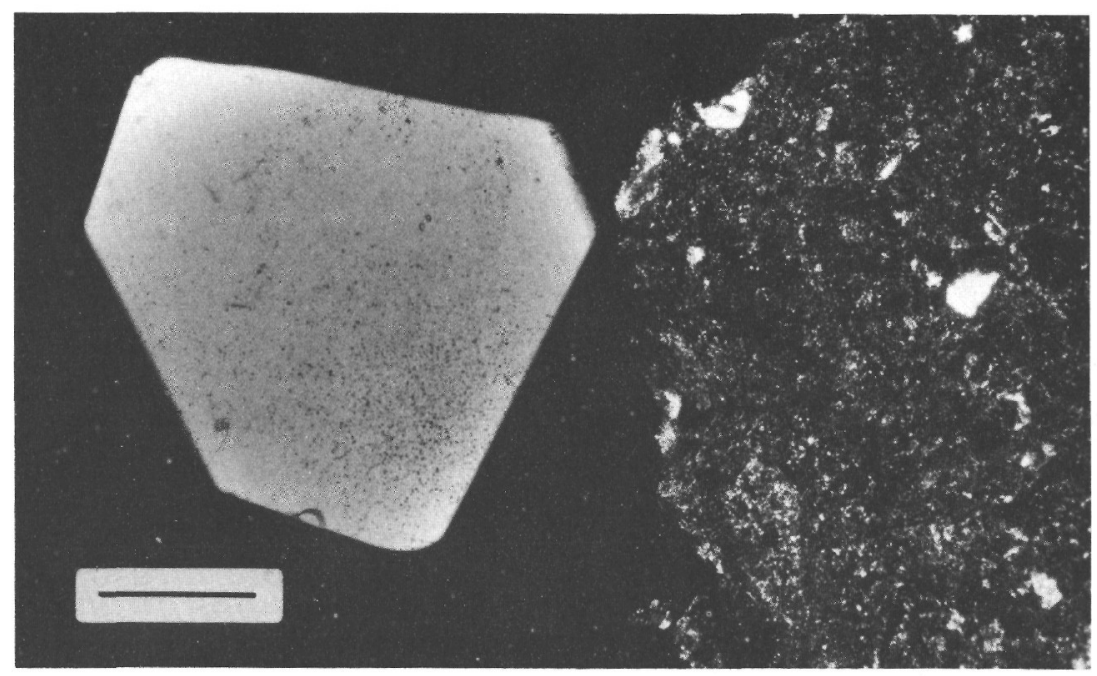

Figure 8. Photomicrograph of Sample 34 (CC). Pumiceous lapilli tuff. Lithoidal rhyolite fragment and idiomorphic quartz crystal. Crossed polarizers. Length of scale bar is $500 \mu$. 


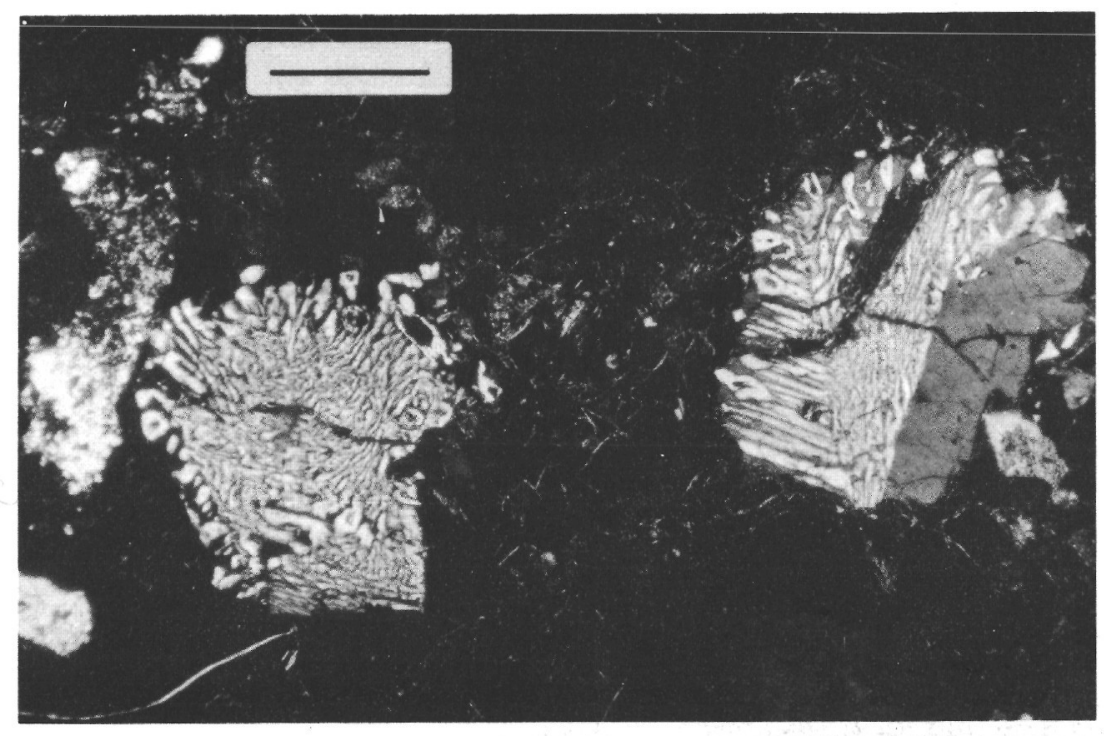

Figure 9. Photomicrograph of Sample 34 (CC). Pumiceous lapilli tuff. Granophyre fragments. Crossed polarizers. Length of scale bar is $500 \mu$.

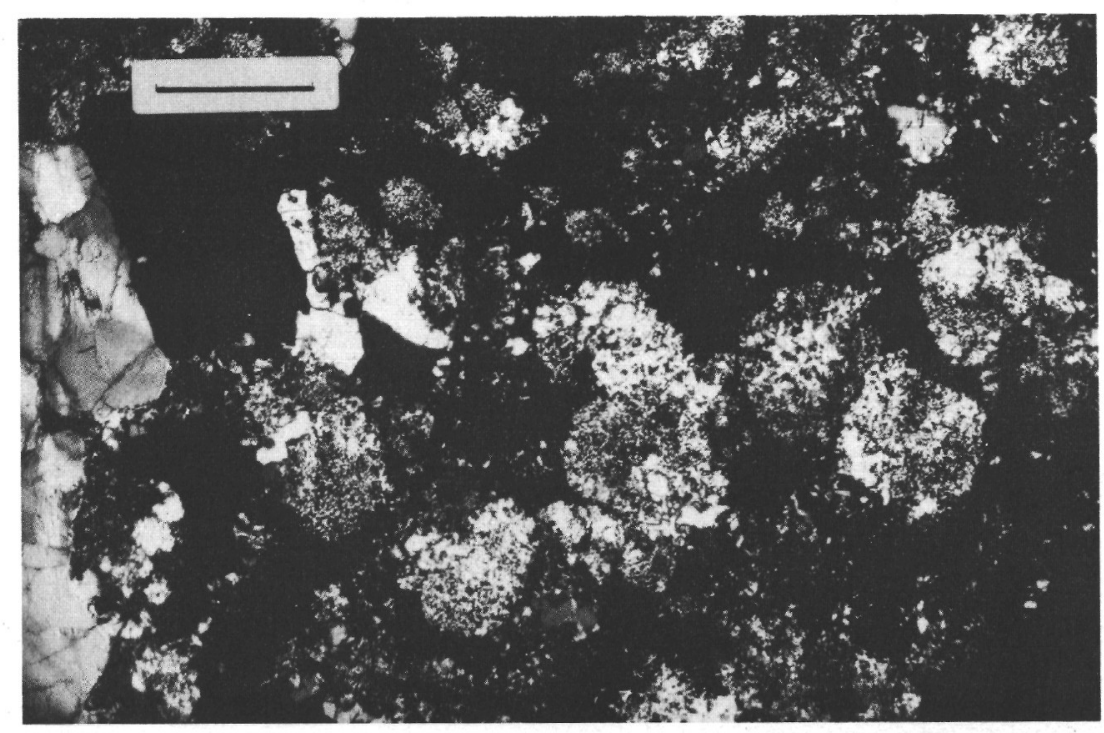

Figure 11. Photomicrograph of Sample 39-1(143-144). Pumiceous lapilli tuff. Accessory fragment, showing "snowflake" devitrification texture. Plagioclase phenocryst at left. Crossed polarizers. Length of scale bar is $500 \mu$.

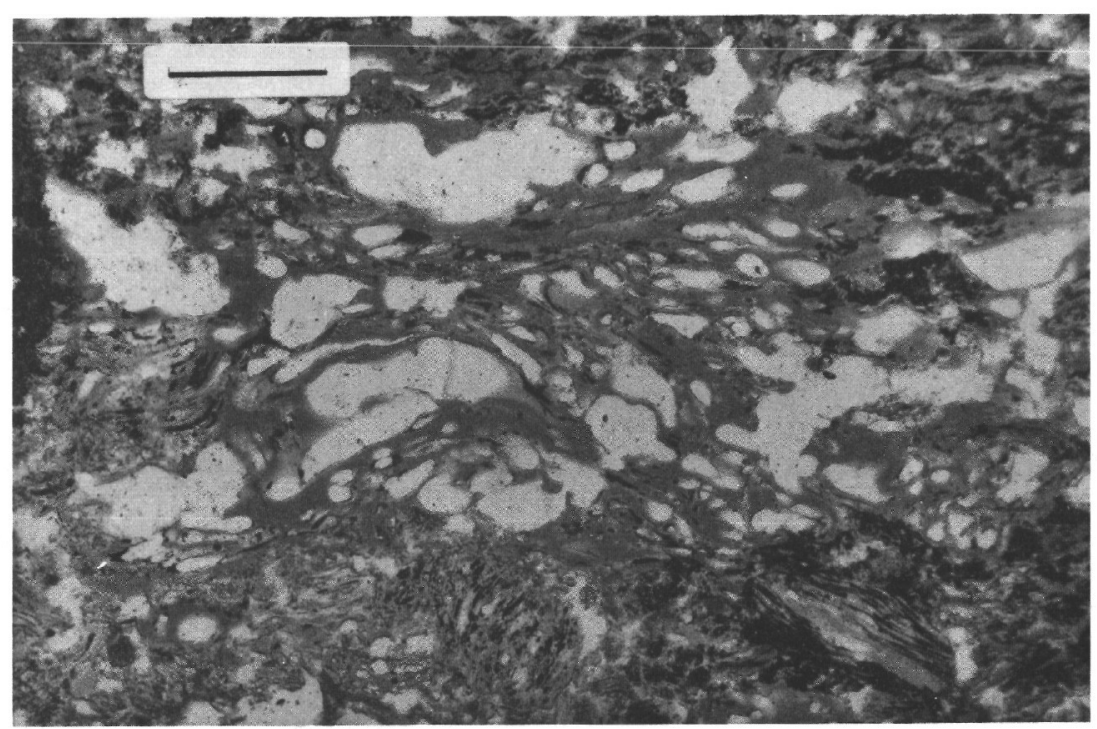

Figure 10. Photomicrograph of Sample 34 (CC). Pumiceous lapilli tuff. Cellular pumice fragment. Plane polarized light. Length of scale bar is $500 \mu$.

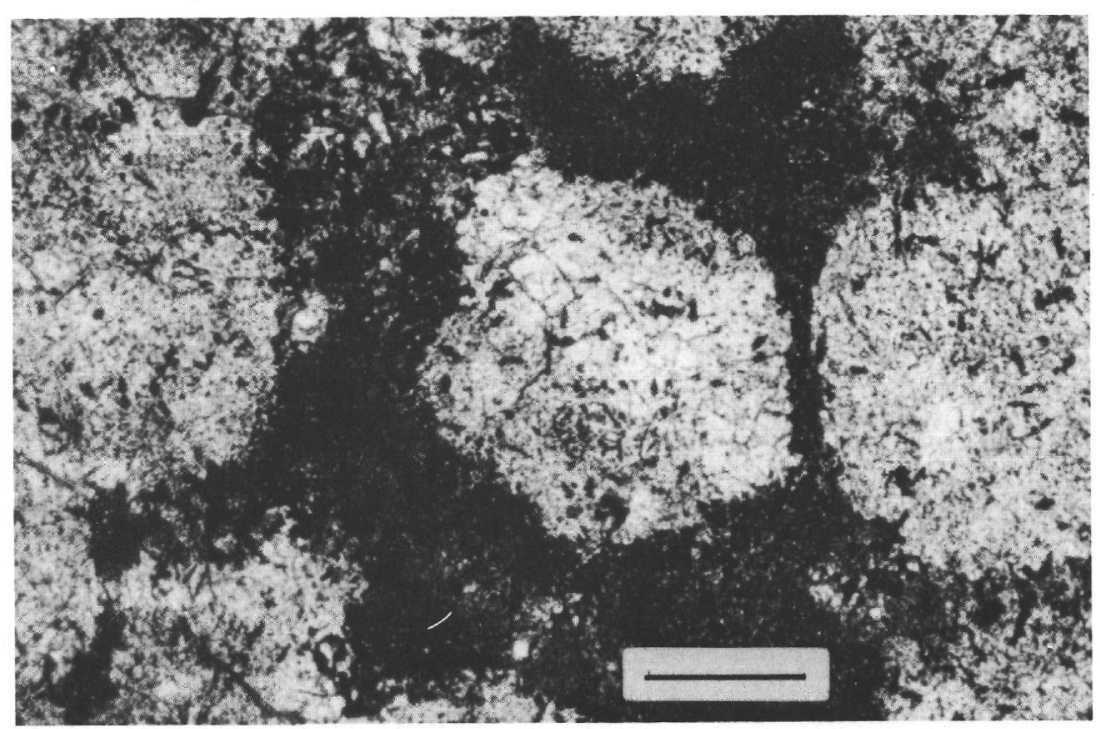

Figure 12. As Figure 11. "Snowflake" devitrification texture, showing concentration of opaque globules around "snowflakes". Plane polarized light. Length of scale bar is $300 \mu$. 


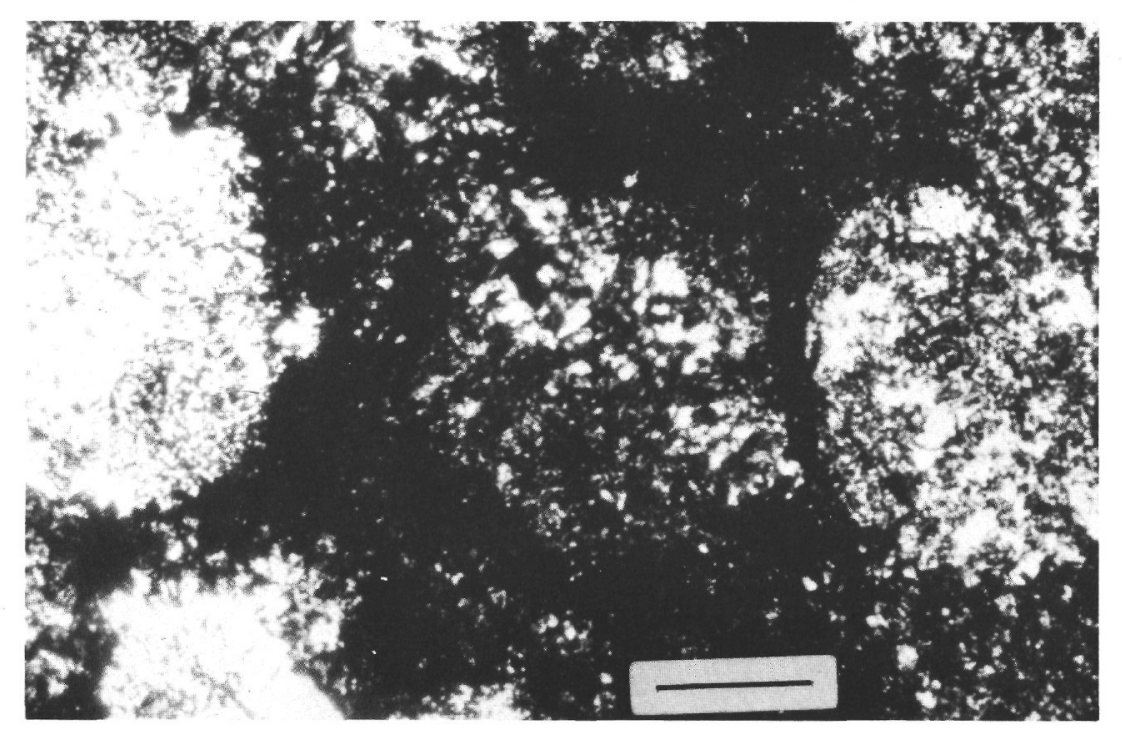

Figure 13. Same view as in Figure 12. Crossed polarizers. Central "snowflake" shows uniform extinction of its micropoikilitic quartz framework. Length of scale bar is $300 \mu$.

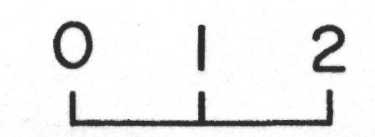

\section{Centimeters}

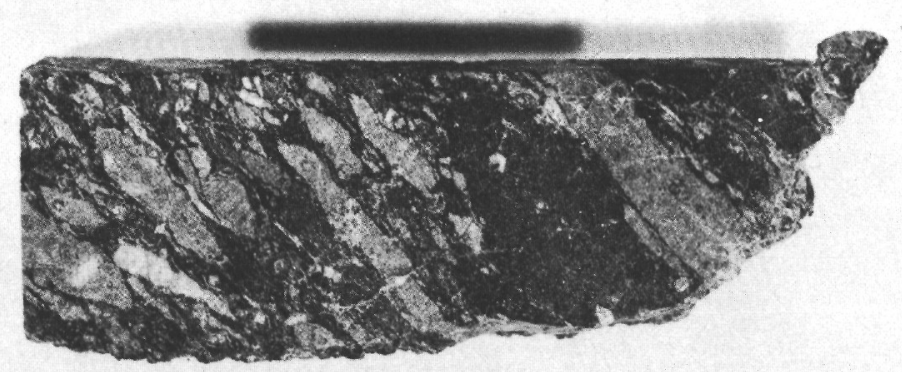

Figure 15. Sample 35-3(90-100). Parallel orientation of lenticular pumice fragments in a vitrophyric matrix.

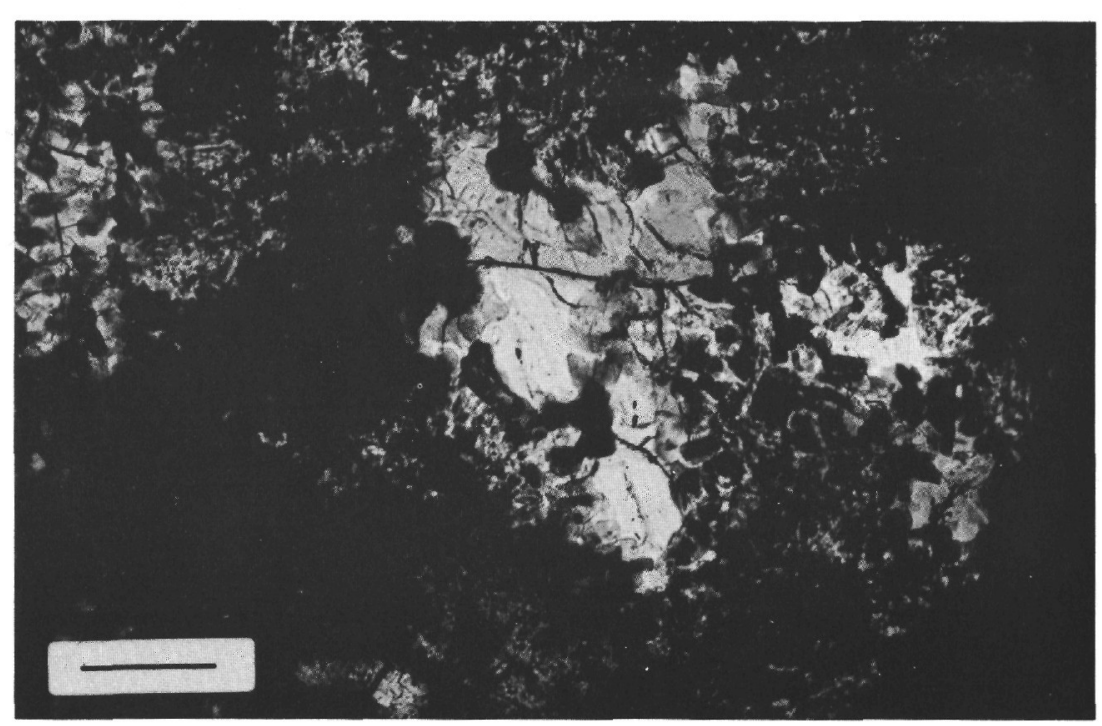

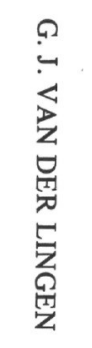

Figure 14. Same thin section as Figure 11. Larger irregular quartz patches in "snowflake" texture. Crossed polarizers. Length of scale bar is $100 \mu$.
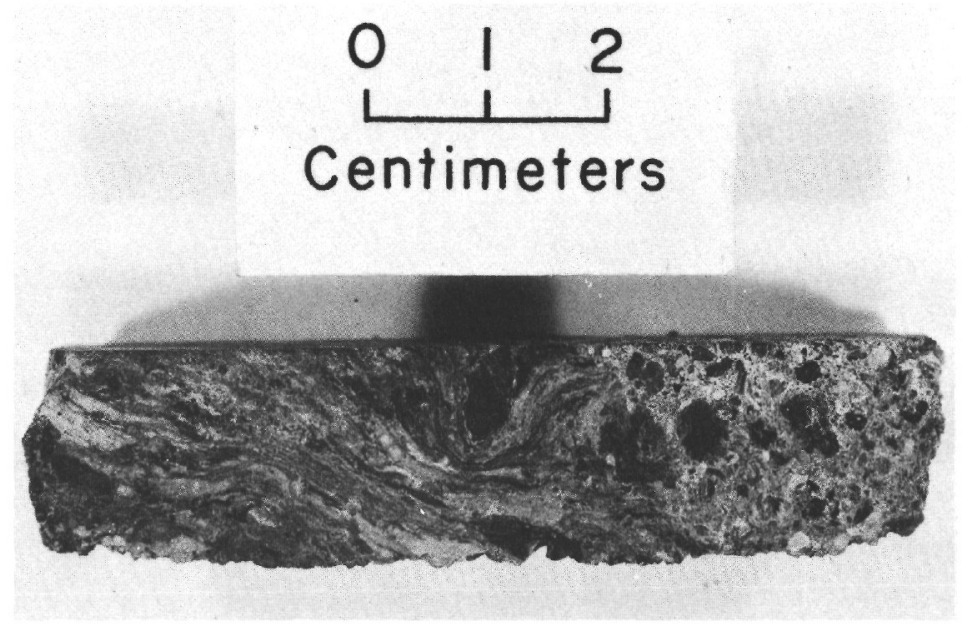

Figure 16. Sample 35-1(70-80). Pumiceous lapilli tuff, showing contact of large fragment? ?) with fluidal texture and finer-grained lapilli tuff. 


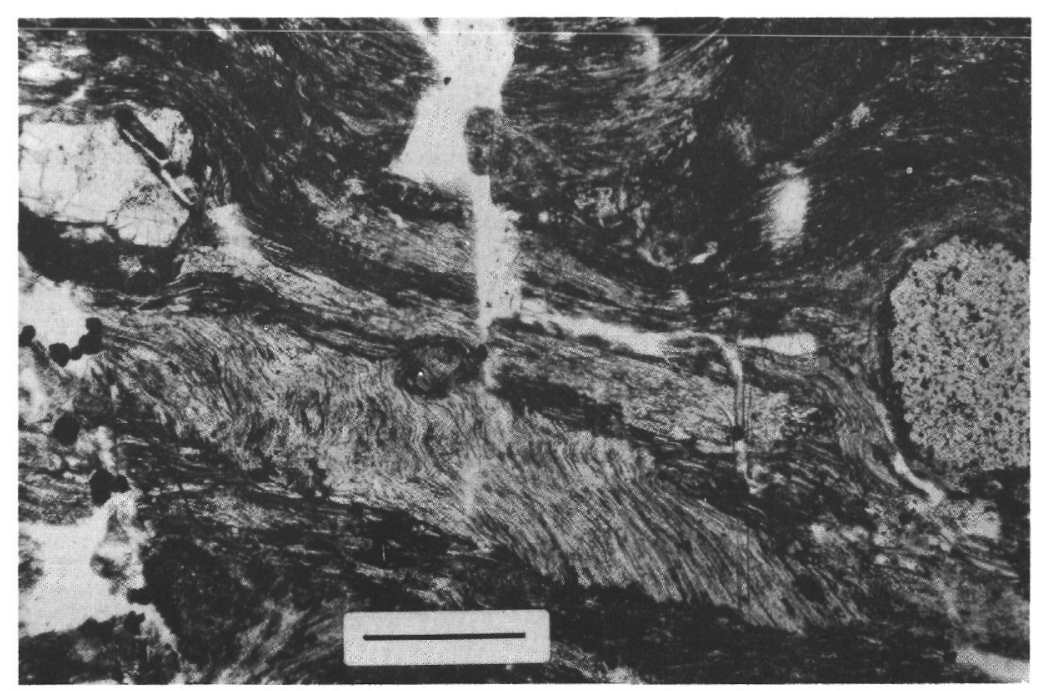

Figure 17. Photomicrograph of Sample 35-3(90-100). Pumiceous lapilli tuff. Lenticular pumice fragments, lithic fragments, and phenocrysts. Plane polarized light. Length of scale bar is $500 \mu$.

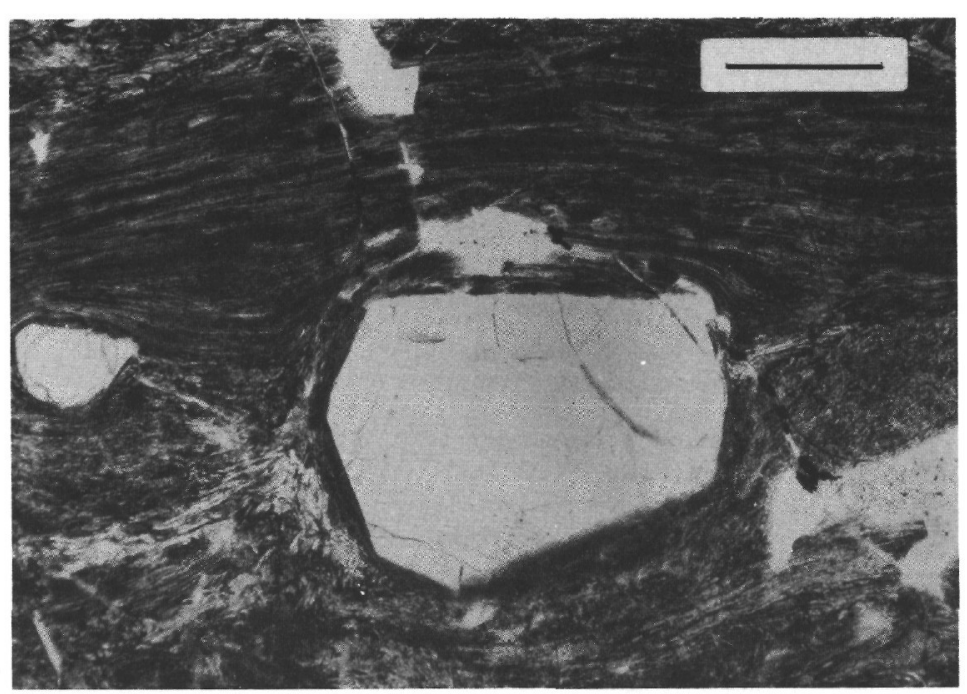

Figure 19. Photomicrograph of Sample 35-3(90-100). Continuous flow lines in glass, being deflected by quartz phenocrysts and pumice fragments. Plane polarized light. Length of scale bar is $500 \mu$.

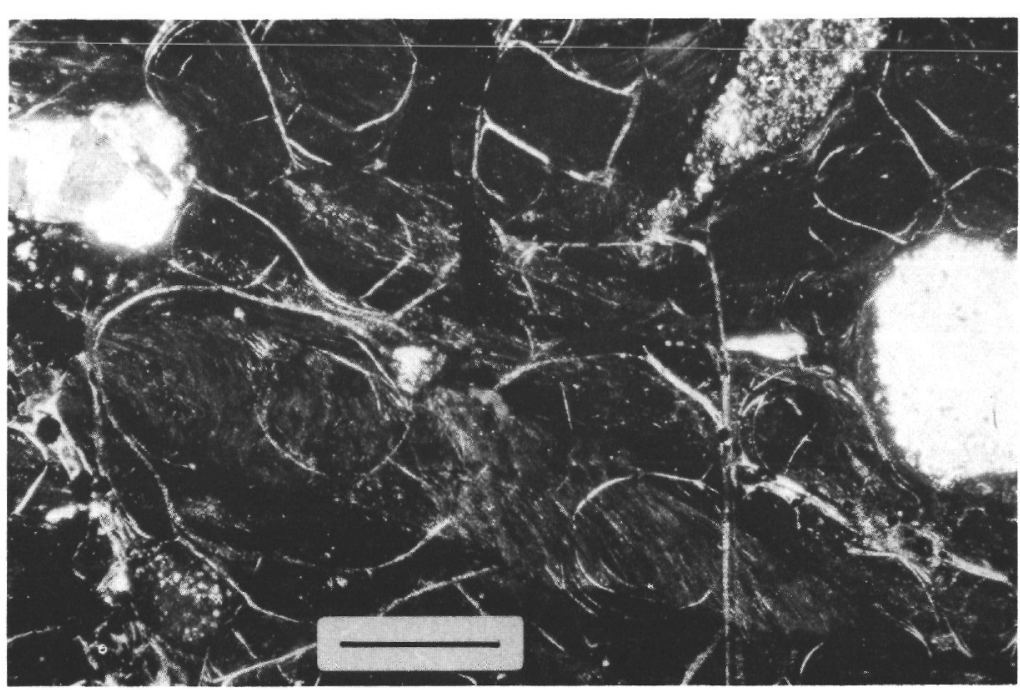

Figure 18. Same view as in Figure 17. Crossed polarizers. Pumice fragments show faint birefringence. Length of scale bar is $500 \mu$.

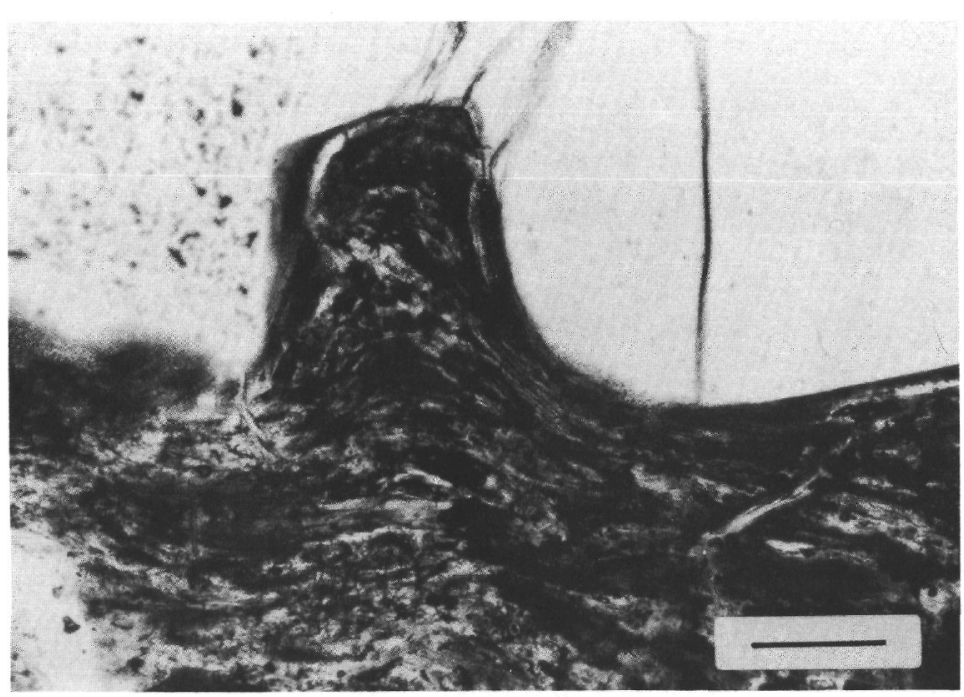

Figure 20. Photomicrograph of Sample 35-3(90-100). Flow lines in glass matrix, conforming to embayement of quartz phenocryst. Plane polarized light. Length of scale bar is $100 \mu$. 
indicated by faint birefringenece in pumice fragments (Figure 18). No vapor-phase crystallization has been noted. There are, therefore, no unambiguous diagnostic features indicating an ash-flow origin for the rocks near the base of Core 35 .

The pumice fragments may be of air-fall origin incorporated in a glassy rhyolite flow. The pumice fragments may still have been in a plastic state or may have become plastic again in the flow. Boyd (1961) has described "collapsed pumice breccias" from Yellowstone Park, U.S.A.. In his description, he states (p. 405): “In many cases, the pumice fragments and matrix are both welded to dense glass, and the rock has been plastically deformed so that the pumice fragments are drawn into streaks". He interprets the origin of these rocks as follows (p. 405): "The pockets of collapsed pumice breccia are formed from masses of pumice and ash dragged from the surfaces of moving flows into the liquid lava beneath." Boyd's description and photomicrographs of these pumice breccias very much resemble the rocks at the base of Core 35 , and his interpretation is similar to ours.

On the other hand, the sample of Figure 16 may be part of an accessory fragment. A sample cut from a higher position in Core 35 (Figure 16) also shows a flow texture with drawn-out pumice fragments, but in this sample, a sharp contact with a brecciated part can be seen, suggesting that the "flow rock" is a fragment.

Most of the nontuffaceous fragmental rock of Unit 4 does not contain pumice fragments, but mainly fragments of vitrophyric rhyolite, no different from the groundmass. These parts of Unit 4 are therefore more monolithologic. The fragments vary in size with a maximum observed of 4 $\mathrm{cm}$. It should be stressed again, however, that the core diameter is only $64 \mathrm{~mm}$, which happens to be exactly the size boundary between lapilli and blocks (and bombs). Parts of the core which look like lava flows may well be large blocks, which, according to Parsons (1969), can be up to several hundred feet across in volcanic breccias.

Keeping these restrictions in mind, the nontuffaceous parts of Unit 4 could well be interpreted as glassy rhyolite flows which incorporate accessory fragments and have undergone some autobrecciation.

\section{UNIT 5}

Core recovery in Unit 5 is better than in Unit 4 . Considering the fact that Cores 49 and 50 came up empty, recovery is 30.1 percent. Disregarding cores 49 and 50 , recovery is 39.8 percent.

The rocks are more homogeneous than those in Unit 4. Locally they are fragmented (Figures 22 and 23), but large parts of some cores seem to be undisturbed (as in Cores 45 and 48). Fragments are generally angular and lapilli size (core size limits the detection of larger blocks). Both fragmental and homogeneous rocks are monolithologic vitrophyric rhyolites. Fluidal banding is virtually omnipresent, even in the fragments (Figures 23-25; see also core photographs in Part I).

The glassy groundmass has been devitrified or argillized to various degrees, but some unaltered glass is locally preserved. Perlitic texture is present throughout Unit 5 (Figure 26) and can generally still be observed in the altered parts. Phenocrysts are almost exclusively quartz and plagioclase (Figures 27 and 28). Since most plagioclase crystals show zoning, their compositions can only be given within broad limits, which range from basic oligoclase to medium andesine. This range is similar to the one for plagioclase phenocrysts in Unit 4. Some plagioclase phenocrysts give the impression of being corroded (Figure 28), but closer examination reveals that these phenocrysts consist of aggregations of smaller crystals, the boundaries of which are irregular, differing in this aspect from twin boundaries. Such aggregates can be formed by synneusis, a "process of drifting-together and mutual attachment of crystals suspended in a melt" (Vance, 1969, p. 7).

Ferromagnesian minerals are virtually absent. Sporadic aggregates of opaque and chloritic material, however, may be pseudomorphs after ferromagnesian minerals (Figure 29). The original mineral may have been either hypersthene or fayalitic olivine, both of which occur in rhyolites.

Most of the rocks in this unit have been devitrified and/or argillized. Devitrification is generally fairly complete, but some glass is preserved locally. Spherulites are the common devitrification product. In hand specimen, the spherulites give the rock a "salt-and-pepper" appearance (Figures 24 and 25). Basically, there are two types of spherulites, rosette spherulites (Figures 30,31, and 33) and radialfibrous spherulites (Figures 32 and 34).

In thin section, under ordinary light, the rosette spherulites do not show internal structures. They are mainly spherical in section with a lobe-shaped circumference. The lobes are separated by radial-dendritic arrangements of globulites (Figure 33) which generally terminate before reaching the center. Globulites are also concentrated around the spherulites, as if swept out by the growing spherulite. A similar feature was produced by experimental devitrification of natural rhyolite glass by Lofgren (1971).

Under crossed polarizers, the rosette spherulites show an extinction cross typical for radial aggregates (Figure 31 ). Some rosette spherulites show a concentric structure consisting of a core and an outer rim separated by concentrated globulites (Figure 35). This suggests two stages in the growth of these spherulites.

The radial-fibrous spherulites obtain their fibrous character from an arrangement of globulites radiating from the center to the outer rim (Figure 34). Under crossed polarizers, the radial-fibrous spherulites also show an extinction cross.

Nucleation of spherulites on phenocrysts has been reported in the literature (Ewart, 1971), but in the rocks of Unit 5, this seems to be extremely rare (Figure 36). Most spherulites have originated without any apparent nucleus and seem to be controlled by perlitic cracks. On the other hand, many radial-fibrous spherulites seem to have nucleated on rosette spherulites (Figures 37 and 38). This would suggest that the radial-fibrous spherulites are the result of a later devitrification phase than the rosette spherulites. In rare instances, there seems to be a third stage of spherulite formation. Some radial-fibrous spherulites have concentric rings around them, which, in normal light, look structureless. (Figure 39). As such, they resemble the rosette spherulites. However, these rings have a yellow color 


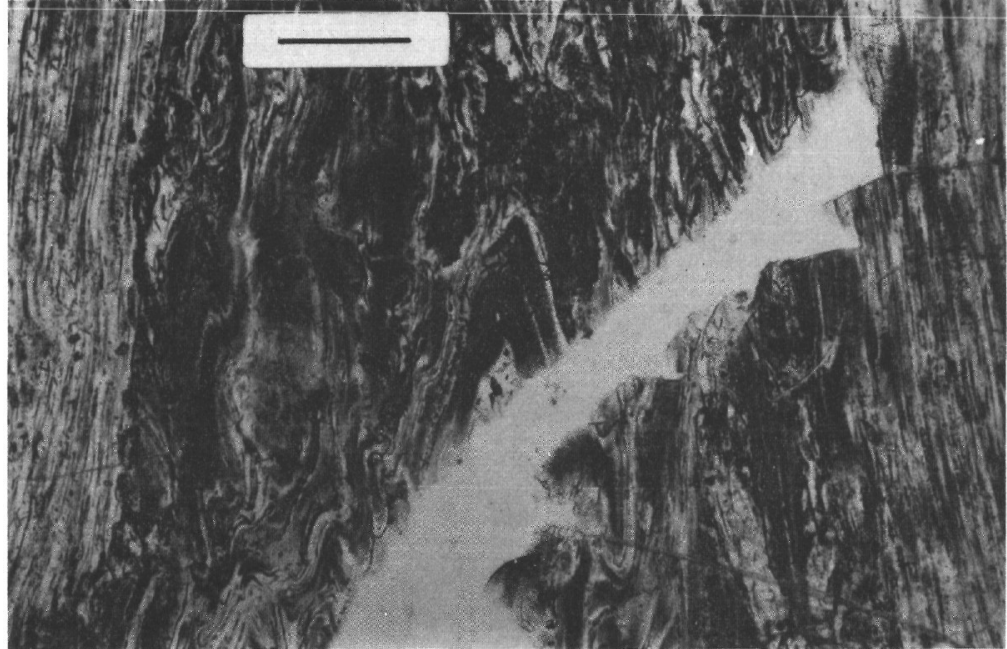

Figure 21. Photomicrograph of Sample 35-3(90-100). Microfolding of flow lines in glass matrix. Note fibrous pumice fragments left and right of microfolded area. Plane polarized light. Length of scale bar is $100 \mu$.

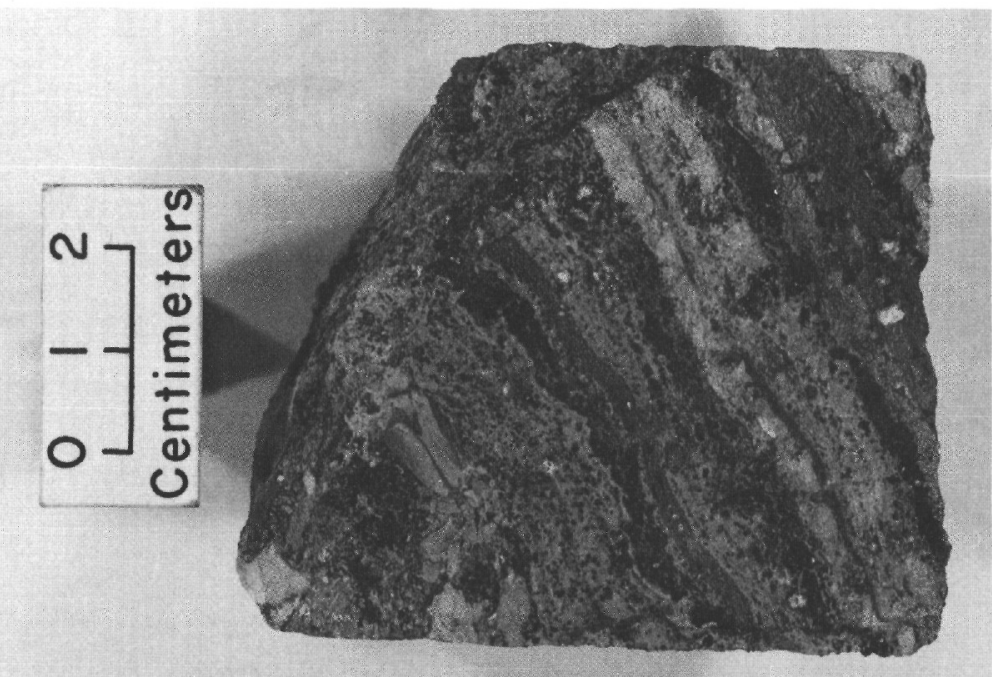

Figure 23. Sample 45-2(128-135). Fragmental spherulitic vitrophyric rhyolite. Large fragment showing fluidal banding and spherulites ("salt and pepper" texture). Note plagioclase phenocrysts.

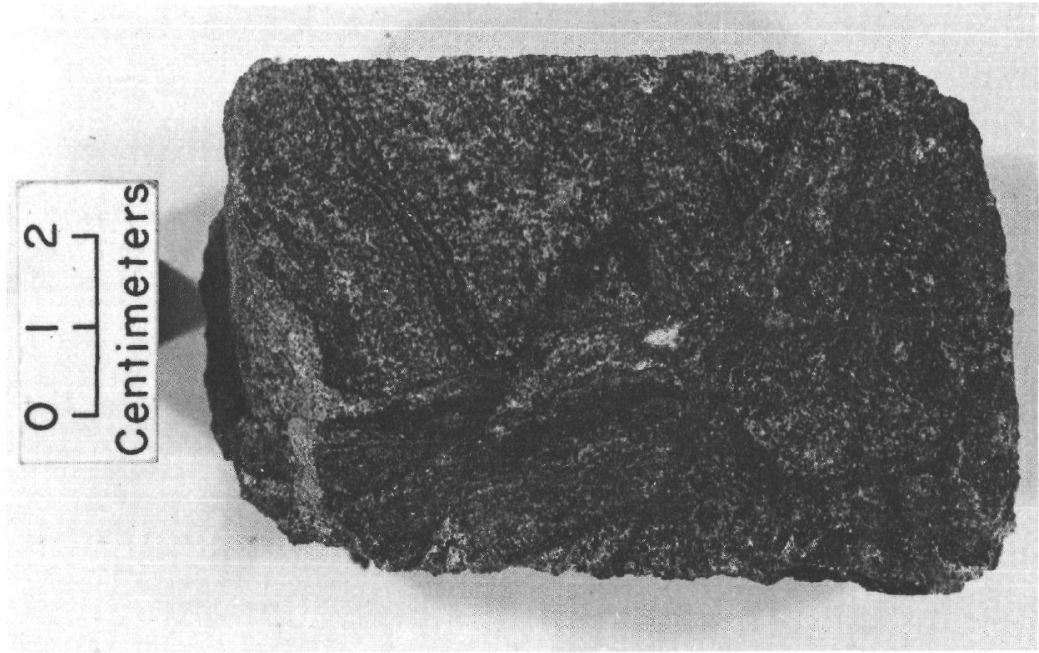

Figure 22. Sample 46-4(107-115). Fragmental spherulitic vitrophyric rhyolite. Note fluidal banding in fragments.

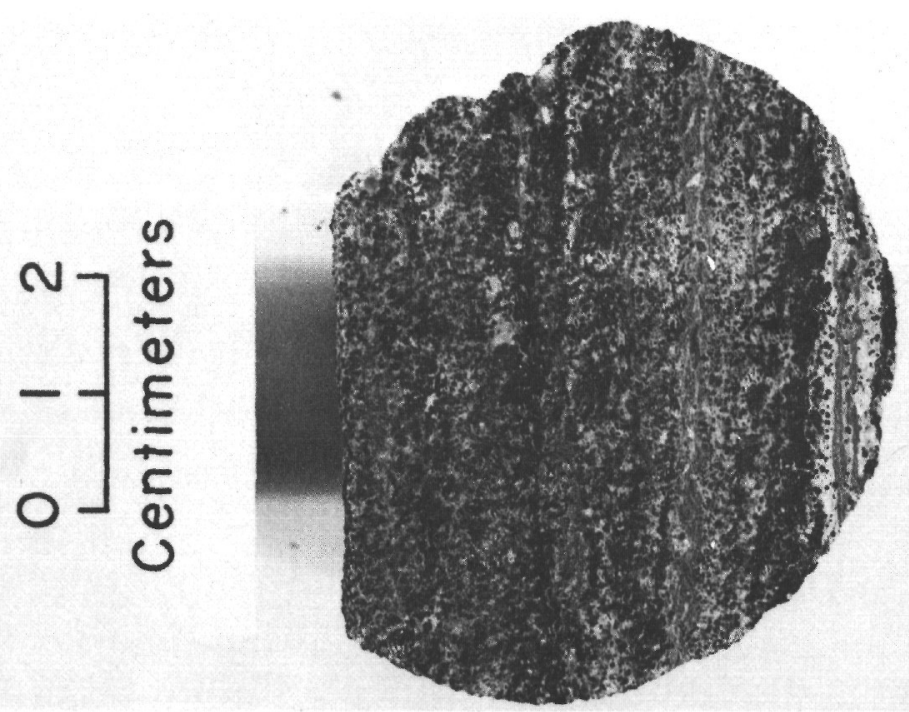

Figure 24. Sample 44 (CC). Spherulitic vitrophyric rhyolite showing "salt and pepper" texture and fluidal banding. 


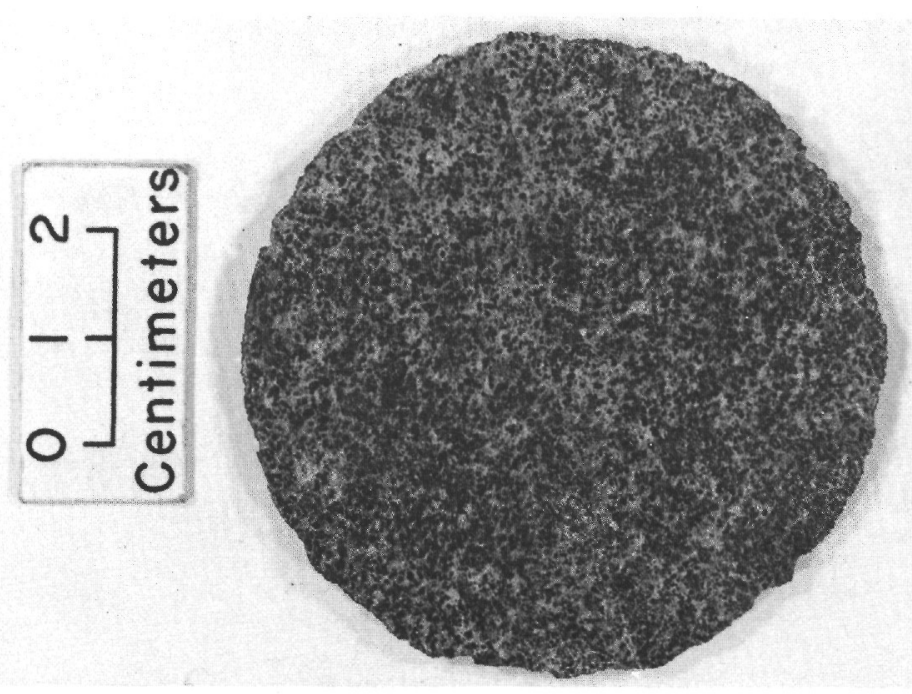

Figure 25. Sample 46-3(126-127). Spherulitic vitrophyric rhyolite showing "salt and pepper" texture.

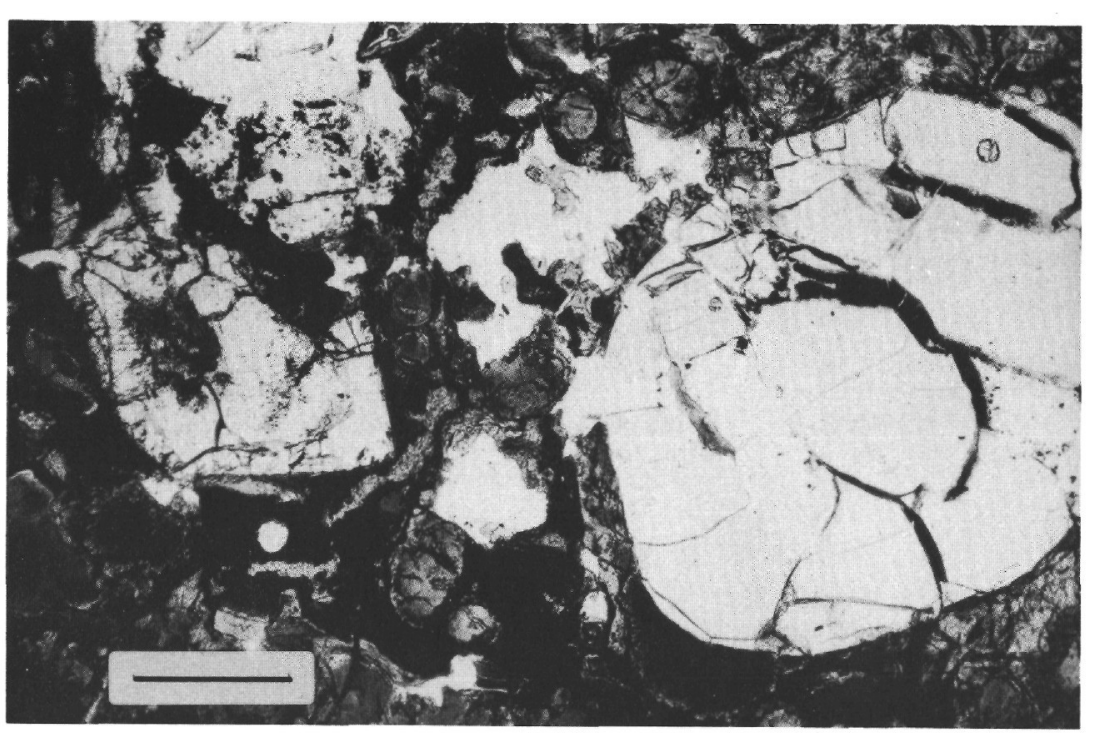

Figure 27. Photomicrograph of Sample 44-1(69-71). Spherulitic vitrophyric rhyolite. Quartz and feldspar phenocrysts in a spherulitic groundmass. Crossed polarizers. Length of scale bar is $500 \mu$.

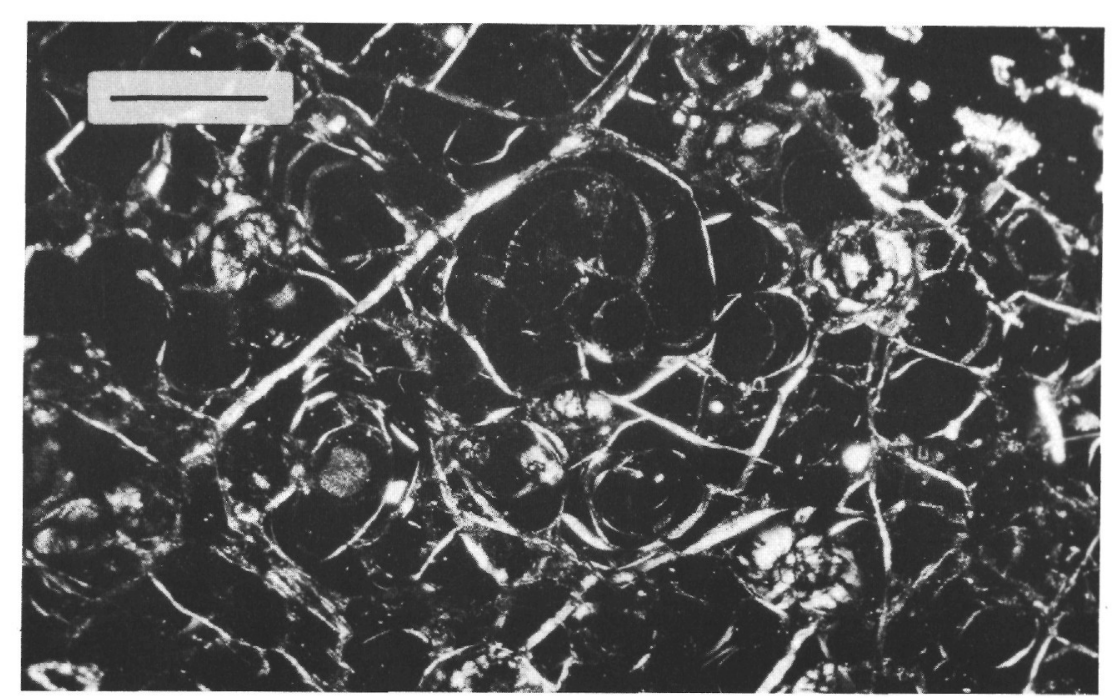

Figure 26. Photomicrograph of Sample 42-1(144-148). Glassy groundmass with perlitic fractures. Note spherulites in the center of some of the perlitic fragments. Crossed polarizers. Length of scale bar is $500 \mu$.

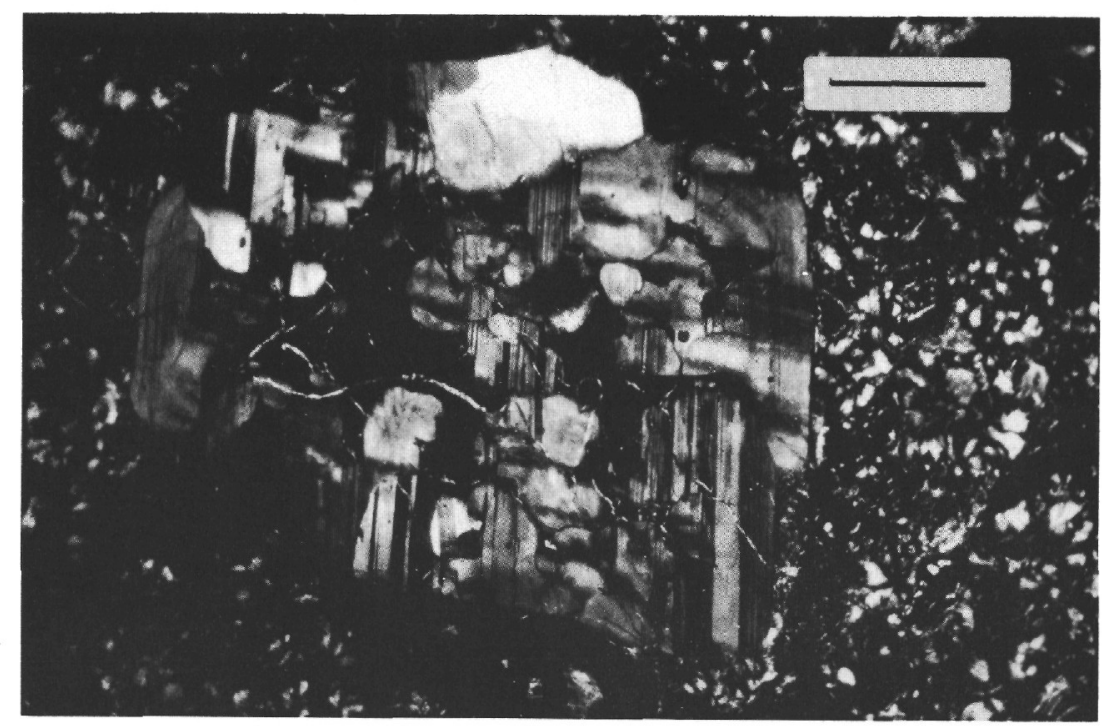

Figure 28. Photomicrograph of Sample 42-1(120-130). Spherulitic vitrophyric rhyolite. Synneusis aggregate of plagioclase crystals. Crossed polarizers. Length of scale bar is $500 \mu$. 


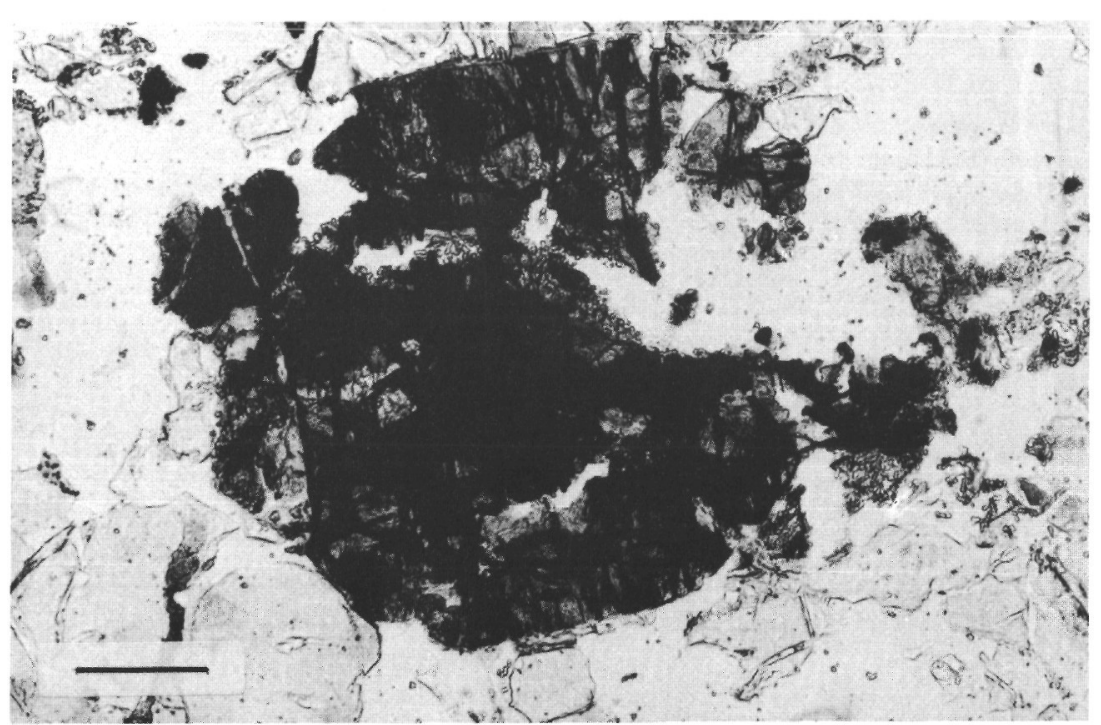

Figure 29. Photomicrograph of Sample 46-4(125-127). Spherulitic vitrophyric rhyolite. Pseudomorph after ferromagnesian mineral. Plane polarized light. Length of scale bar is $80 \mu$.

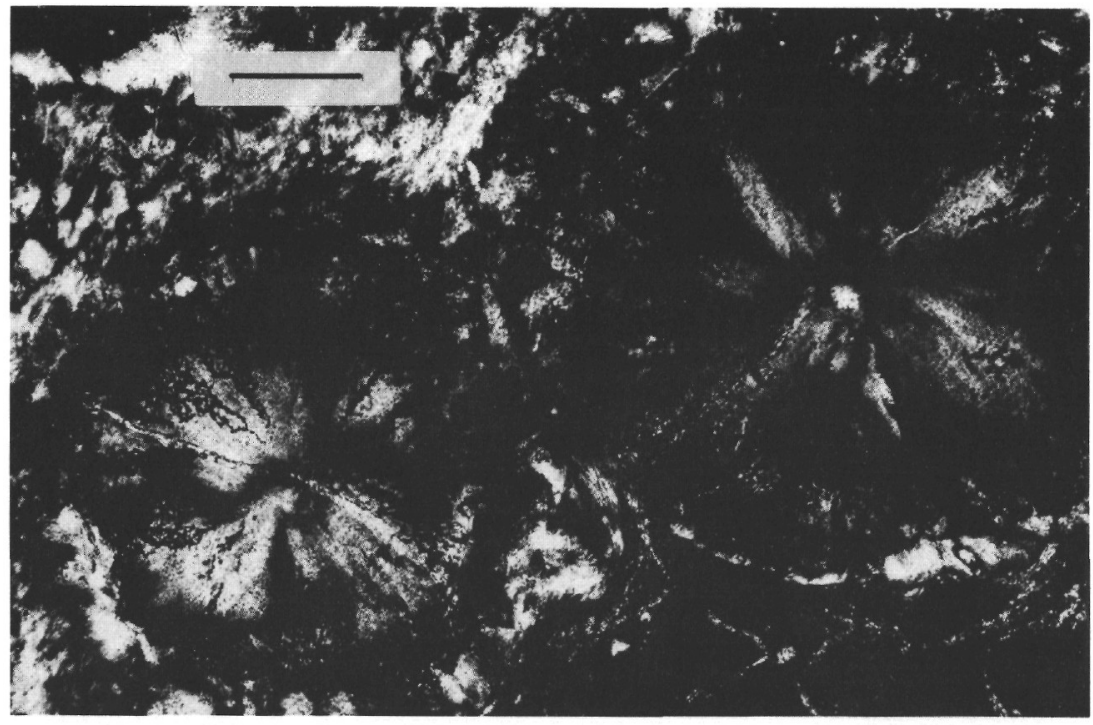

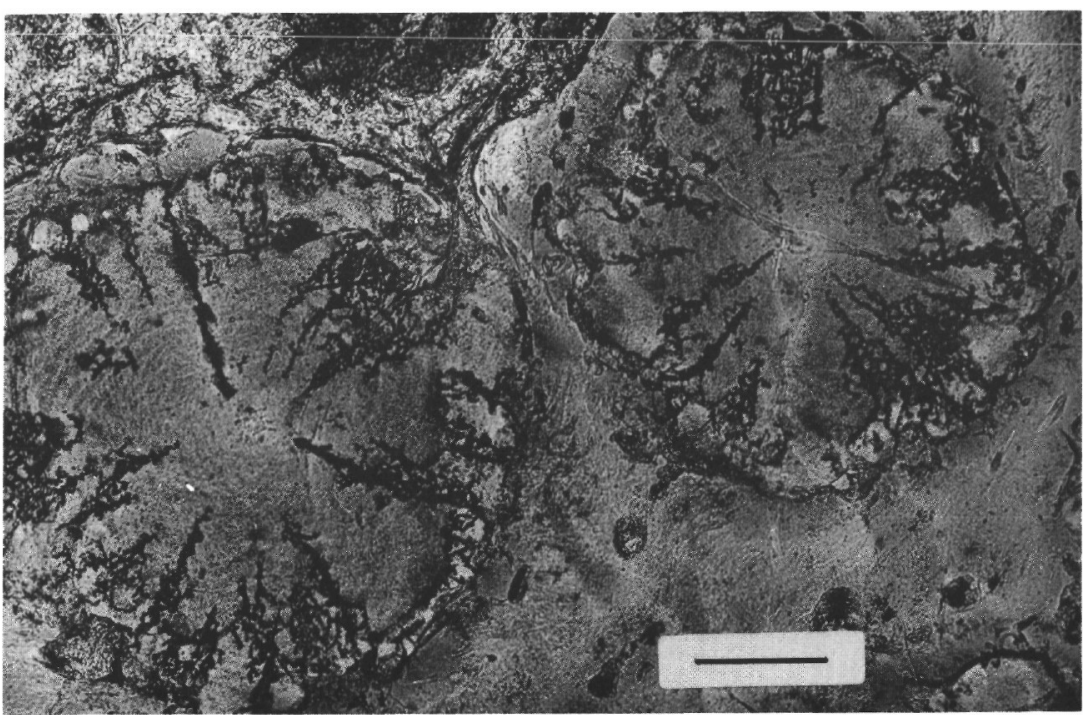

Figure 30. Photomicrograph of Sample 44 (CC). Spherulitic vitrophyric rhyolite. Two rosette spherulites. Note dendritic arrangement of globulites. Plane polarized light. Length of scale bar is $100 \mu$.

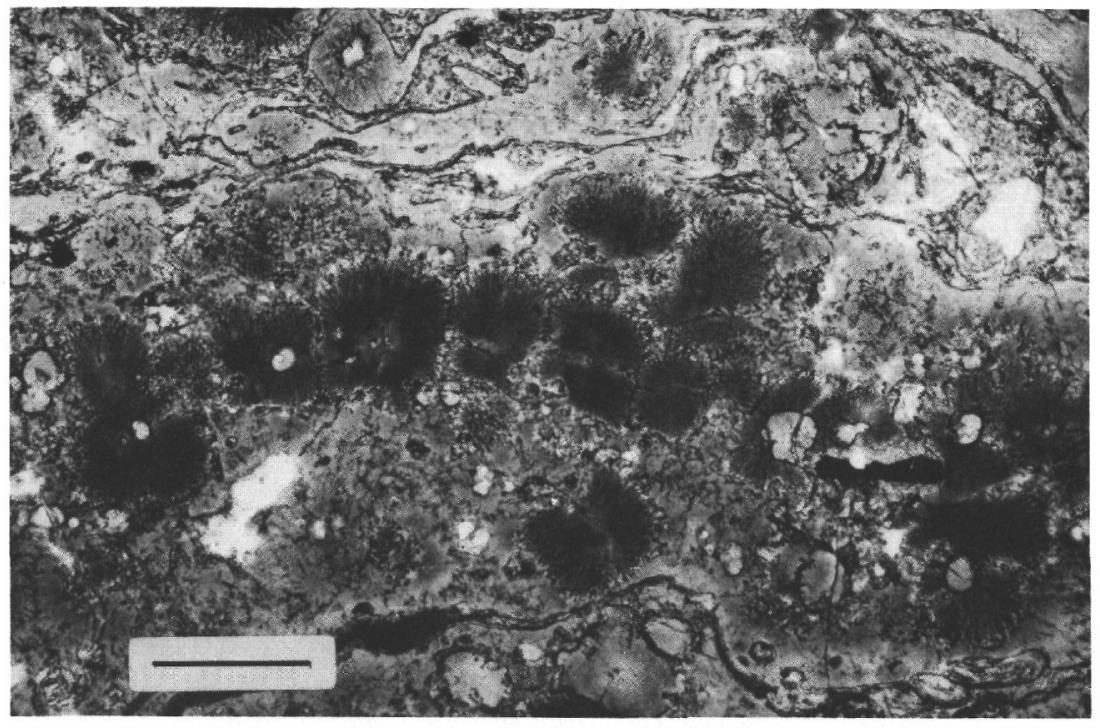

Figure 32. Photomicrograph of Sample 44 (CC). Spherulitic vitrophyric rhyolite. Linear arrangement of radial-fibrous spherulites. Some have nucleated on rosette spherulites. Plane polarized light. Length of scale bar is $300 \mu$. 


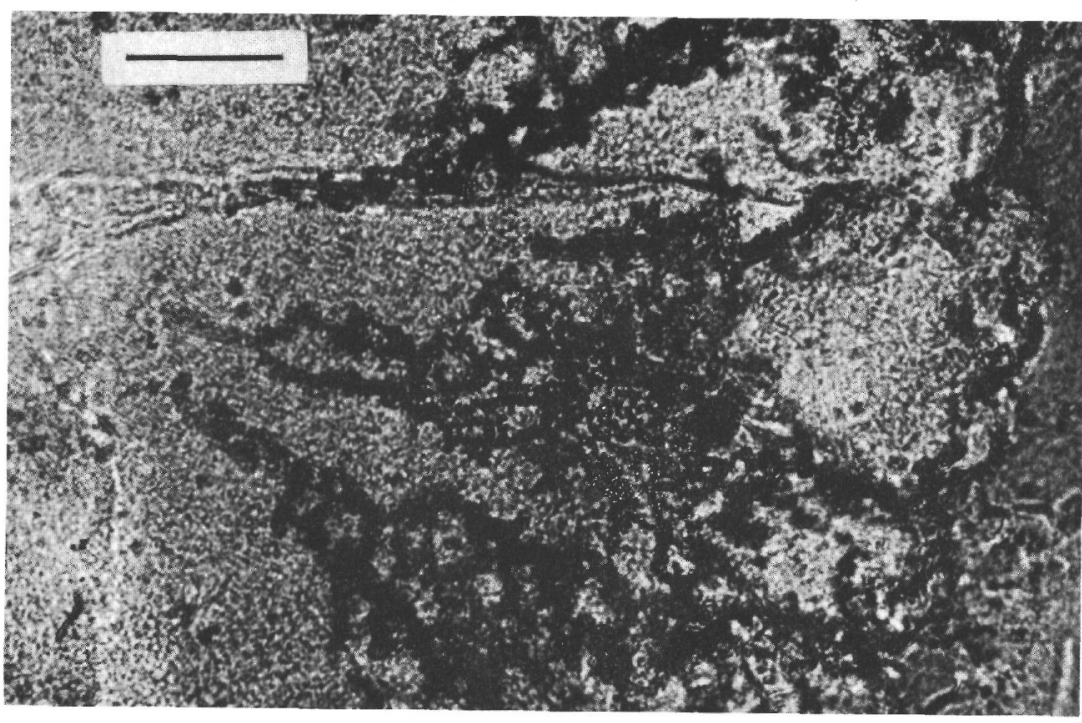

Figure 33. Detail of Figure 30, showing dendritic arrangement of globulites in a rosette spherulite. Plane polarized light. Length of scale bar is $50 \mu$.

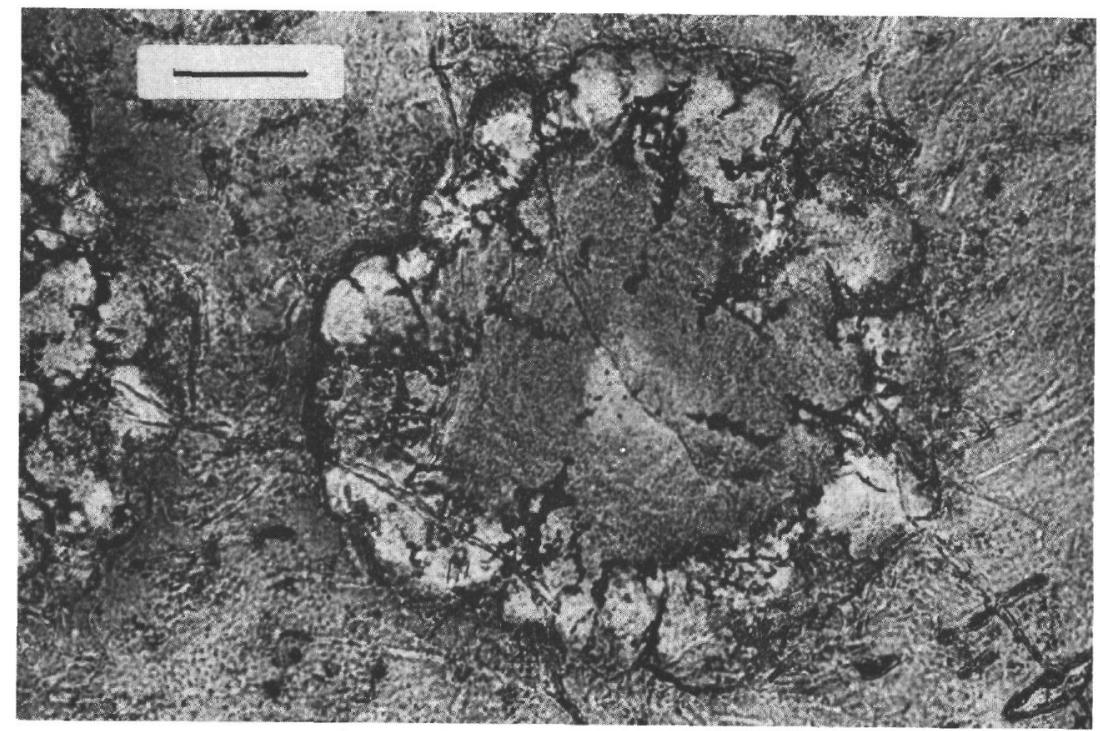

Figure 35. Photomicrograph of Sample 44 (CC). Two-stage rosette spherulite. Note concentric concentration of globulites between the two stages. Plane polarized light. Length of scale bar is $60 \mu$.

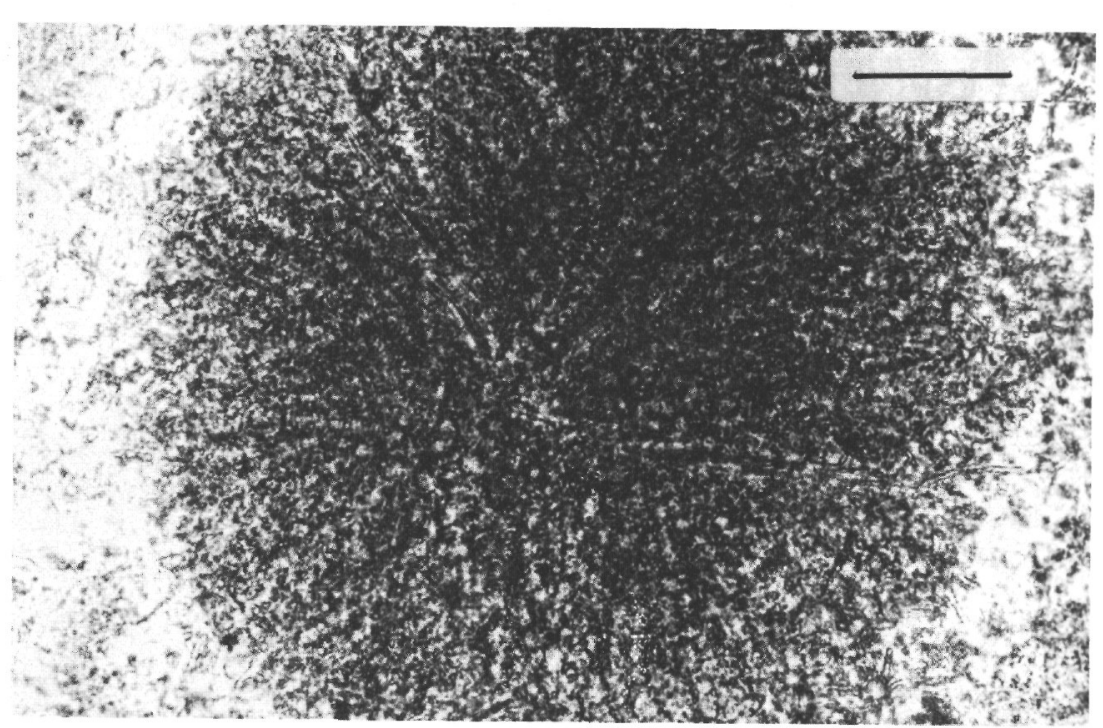

Figure 34. Photomicrograph of Sample 44 (CC). Radial-fibrous spherulite, showing arrangement of globulites. Plane polarized light. Length of scale bar is $50 \mu$.

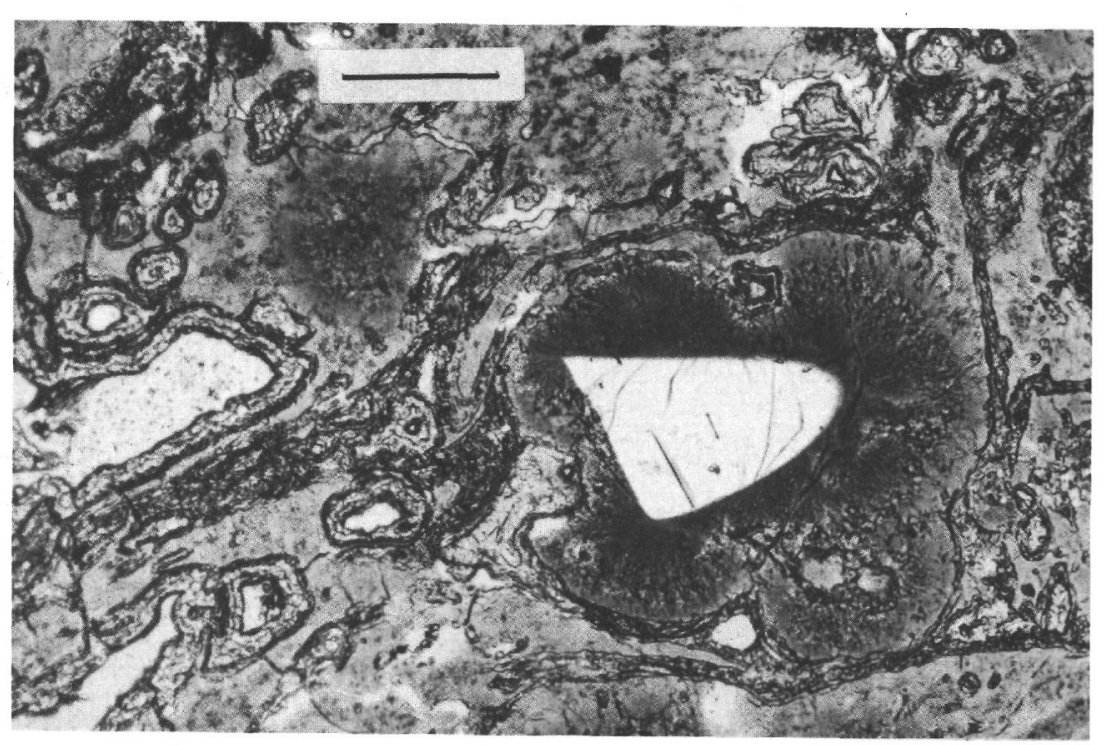

Figure 36. Photomicrograph of Sample 44 (CC). Nucleation of radialfibrous spherulites on a quartz phenocryst. Plane polarized light. Length of scale bar is $300 \mu$. 
in normal light, distinct from the subdued light brown of the rosette spherulites. Occasionally, skeletal feldspar crystals (see Johannsen, 1939, vol. I, p. 12-17) are observed in spherulites, sometimes in the center (Figure 40), sometimes eccentric. These crystals are devitrification products themselves, and it is not clear whether such crystals have acted as nuclei or have grown within the spherulites later.

Many authors have reported on the mineralogical composition of spherulites in rhyolitic rocks. Ewart (1971) found that spherulites in rhyolites form the North Island, New Zealand, are cryptocrystalline intergrowths of $\alpha-$ cristobalite and alkali feldspar (in the albite-anorthoclase range). Ross and Smith (1969) noted that spherulites in the welded tuffs are aggregates of cristobalite and feldspar. Lofgren (1971) found that spherulites in experimentally devitrified rhyolite glass consist mainly of feldspar fibers. Cristobalite was found only sporadically. X-ray diffraction data show that the spherulites in samples from Cores 45 and 46 also consists of cristobalite and feldspar (probably anorthoclase).

Other secondary minerals in these rocks are opal, chalcedony, and zeolite (clinoptilolite). Opal and chalcedony are mainly present as infill of vesicles (Figures 41 and 42). Opal may also line vesicles which may otherwise be empty or have the remaining space filled with chalcedony. Some vesicles are lined by zeolites or by zeolite plus opal. Vesicular rocks were noted, among others, in Cores 42, 44, 45, and 47. According to Lofgren (1971), devitrification of glass is accompanied by a change in volume (up to $10 \%$ ) which results in the formation of what he calls "microlitic cavities". The vesicles in the rocks of Unit 5 may well represent such cavities, though this cannot be established with certainty.

The clinoptilolite has a blocky (prismatic) appearance (Figure 43) and occurs as lining and infill of vesicles as well as being disseminated in the groundmass (Figures 44 and 45).

Secondary ore minerals are mainly hematite and pyrite. The hematite can give the rock a bright red color. Pyrite is often found lining perlitic cracks.

Argillization, in varying degrees, is fairly common throughout Unit 5. Some horizons have have argillized completely (e.g., in Cores 42, 43, 45, and 48). Clay mineralogy has been determined by infrared spectrophotometry and X-ray diffraction. The most common clay mineral is calcium-rich montmorillonite. Halloysite as the major clay mineral was found in one sample $(43, \mathrm{CC})$. It was noted as a minor mineral beside montmorillonite in Sample 45-2(81-83).

There is no obvious correlation between argillization and fragmentation or vesicularity. But again, incomplete core recovery makes detection of such a correlation difficult.

In contrast to Unit 4, no air-fall lapilli tuffs were seen in Unit 5 nor were any of the diagnostic features of ash-flow tuffs observed. Admittedly, strong devitrification and argillization can destroy any such features, but they are also absent from the less altered intervals. Fluidal banding is the most conspicuous characteristic of Unit 5, both in the fragments of the fragmented horizons and in the more homogeneous intervals. The rocks in this unit are therefore interpreted as rhyolitic flows with local autobrecciation. The autobrecciation may be due to rapid quenching under subaqueous conditions (see further).

In most intervals, the fluidal banding dips steeply, up to 90 degrees. Though initial dips of rhyolitic flows are not unusual, the observed dips would suggest some postdepositional tilting. However, it should be kept in mind that it is not known how much the drill string can deviate from the vertical.

\section{SUBAERIAL VERSUS SUBAQUEOUS}

It is of importance for the paleogeography and plate-tectonic history of the southwest Pacific to know whether the Lord Howe Rise rhyolites were extruded subaerially or subaqueously, but diagnostic criteria for this are not easy to establish. Submarine basaltic extrusions have received a great deal of attention, and the presence, for instance, of pillow lavas and palagonitic hyaloclastites seems to be diagnostic for submarine extrusion of basalts (e.g. Nayudu, 1962; McBirney, 1963; Parsons, 1969). Less information is available on submarine rhyolitic extrusions. Parsons (1969 p. 294) states that "Other types of flows, those produced from more viscous or more acid magmas, or both, apparently fragment violently into angular blocks, rather than into pillow-shaped masses, on entering water." A more thorough discussion is given by McBirney (1963), who, on theoretical and experimental grounds, concludes that the formation of ash (pumice) by vesiculation (explosive eruption) is a function of depth and the amount of water dissolved in the magma. For most rhyolitic magmas the limiting depth would be 500 meters. However, very water-rich eruptions could vesiculate in depths of over 2000 meters. His reasoning could be applied to the pumiceous lapilli tuffs of Unit 4. Unfortunately, as the original water content of the Lord Howe Rise rhyolites is difficult to establish, this line of reasoning does not provide satisfactory answers.

The lapilli tuffs in Unit 4 are products of explosive eruptions. As discussed above, these could occur subaerially or subaqueously. However, pumice fragments with unconnected vesicles would float to the surface, thus becoming separated from denser fragments (Fiske, 1963). The pumiceous lapilli tuffs of Unit 4 are a mixture of cellular pumice, fibrous pumice, and nonvesicular vitrophyric rhyolite. This would suggest a subaerial or very shallow water eruption for these tuffs.

The ubiquitous glassy character of the rocks in both units suggests rapid cooling. This may be especially significant for those horizons interpreted as lava flows. It is known from subaqueous basaltic flows that rapid quenching results in the development of hyaloclastic crusts (McBirney, 1963), and it seems likely that hyaloclastites can also develop in subaqueous rhyolitic flows. The fragmented parts in the nontuffaceous horizons may represent such hyaloclastites. This may be especially the case for rocks in Unit 5. The process can of course be regarded as a form of autobrecciation. The more homogeneous intervals in Unit 5, with well-developed fluidal banding, may represent the unaffected interiors of flows. Rapid quenching, however, can also occur in nonmarine environments; extrusion in lakes or under ice, 


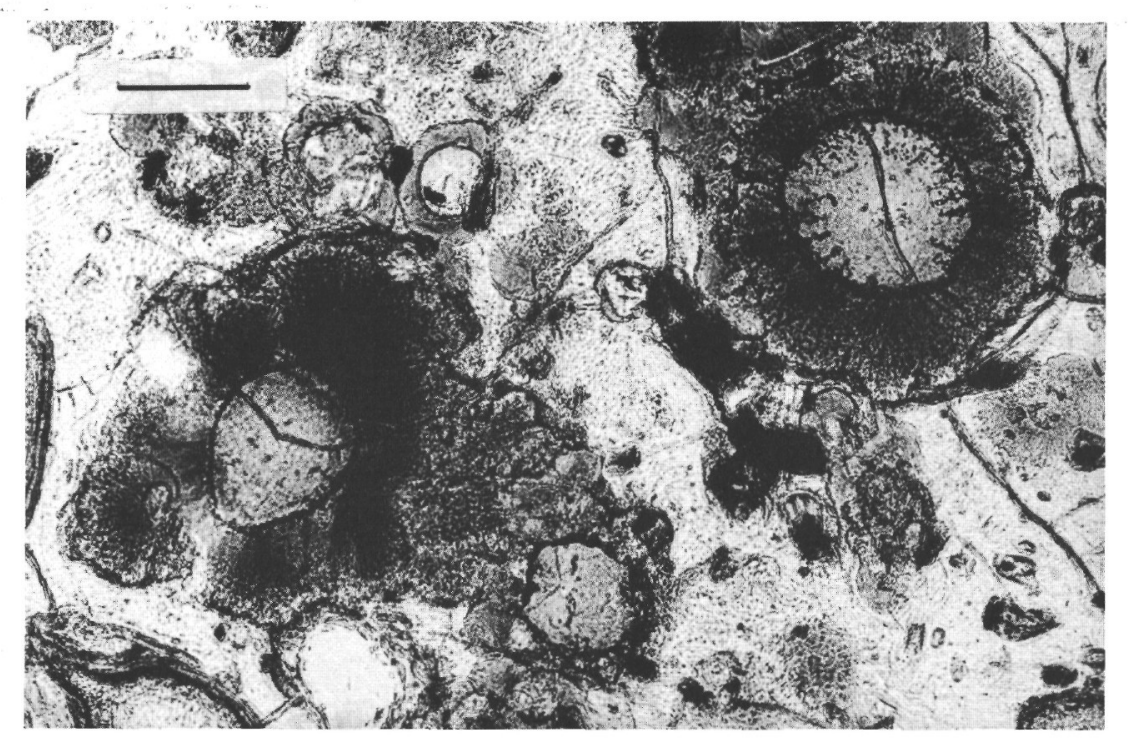

Figure 37. Photomicrograph of Sample 44 (CC). Nucleation of radialfibrous spherulites on rosette spherulites. Plane polarized light. Length of scale bar is $100 \mu$.

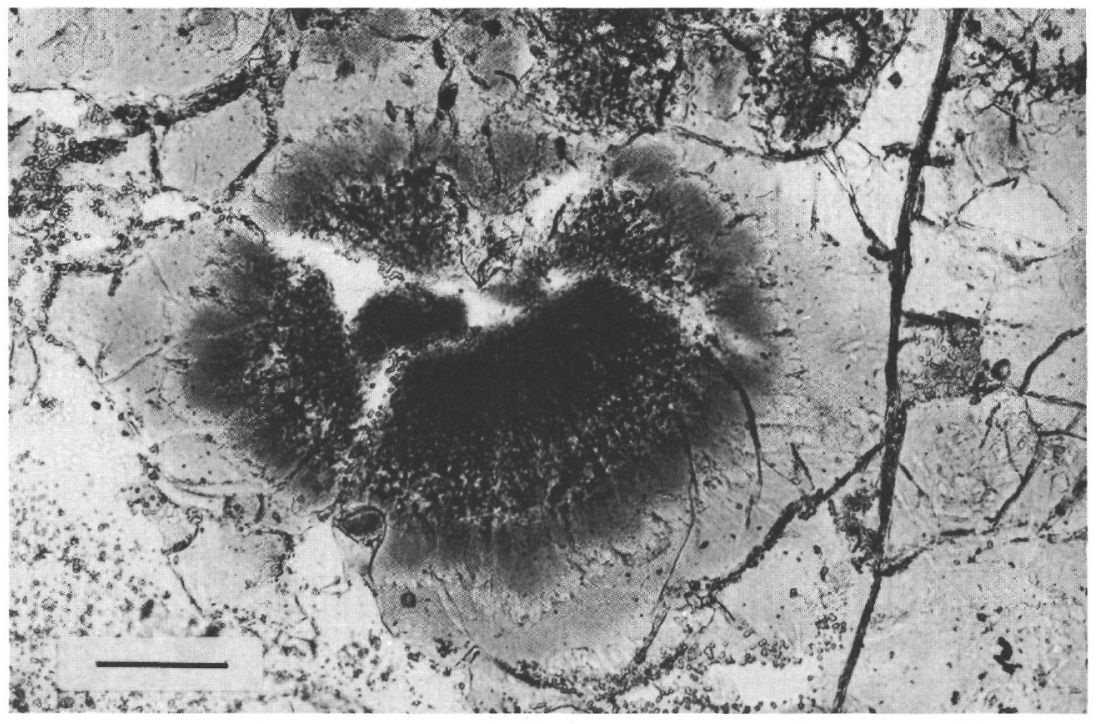

Figure 40. Photomicrograph of Sample 44 (CC). Skeletal feldspar crystal in center of rosette spherulite. Plane polarized light. Length of scale bar is $80 \mu$.

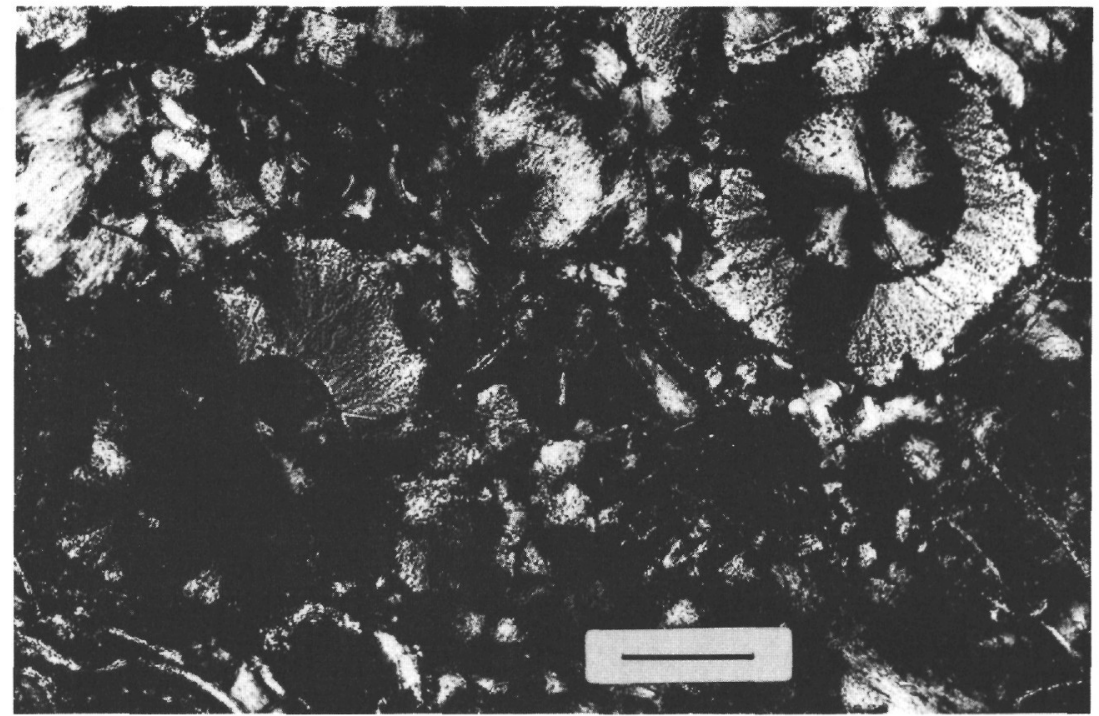

Figure 38. Same view as in Figure 37. Crossed polarizers. Length of scale bar is $100 \mu$.

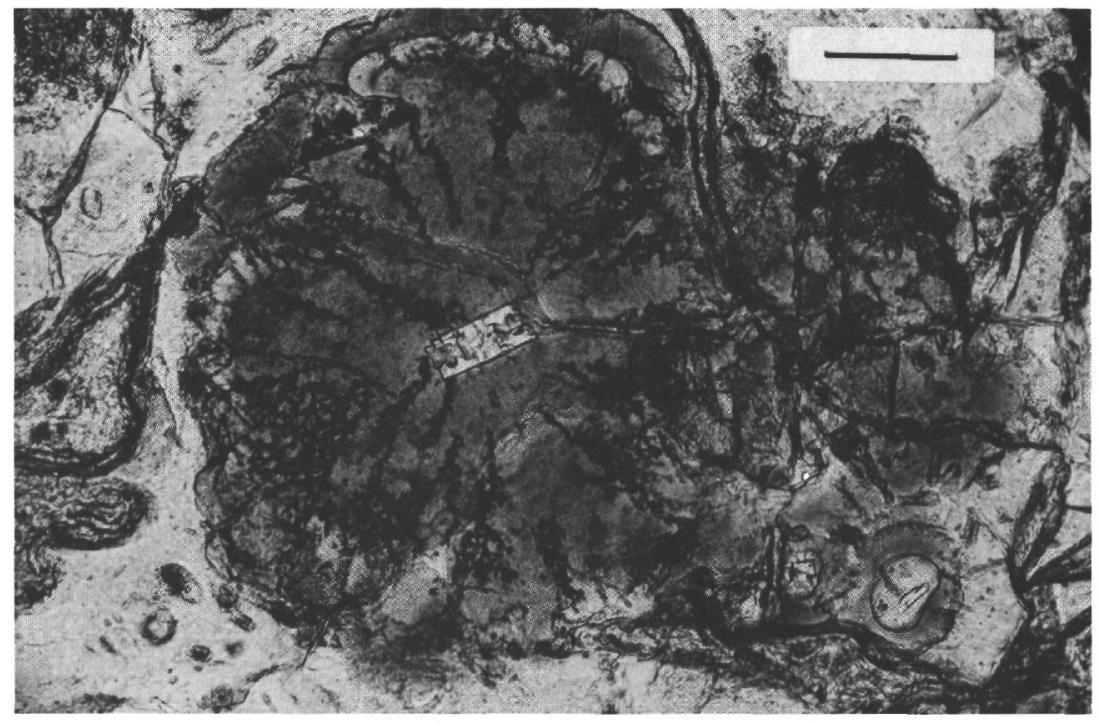

Figure 39. Photomicrograph of Sample 46-4(125-127). Nucleation of rosette-type spherulite on a radial-fibrous spherulite. Plane polarized light. Length of scale bar is $80 \mu$. 


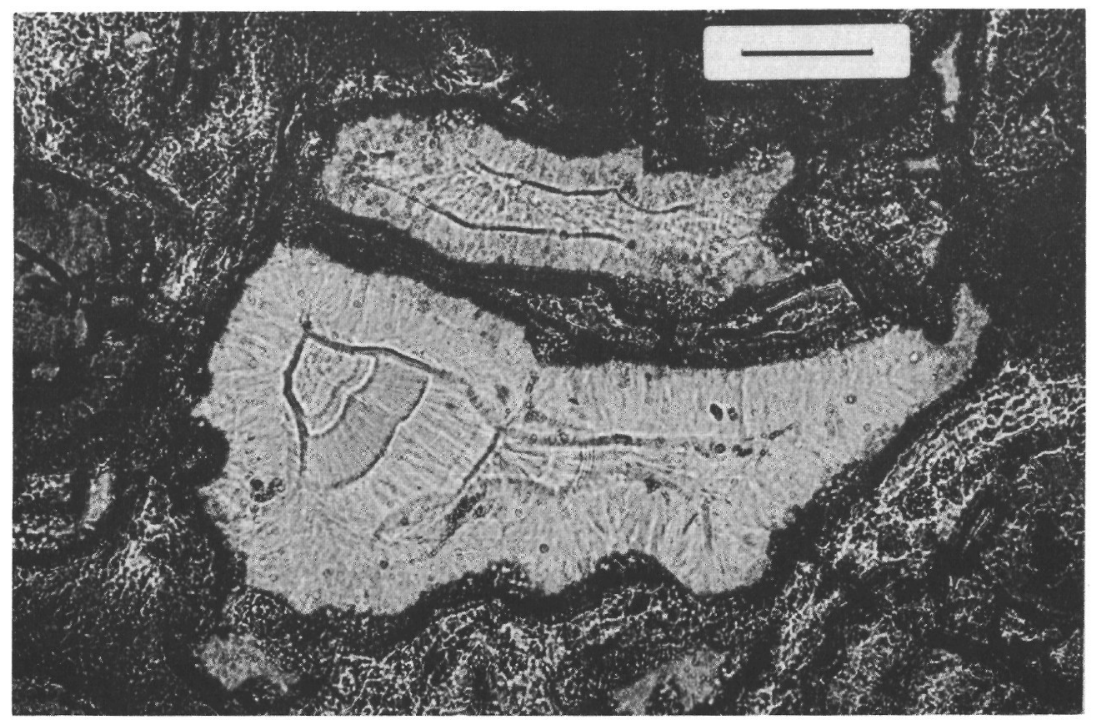

Figure 41. Photomicrograph Sample 44 (CC). Vesicles, filled with chalcedony. Plane polarized light. Length of scale bar is $100 \mu$.

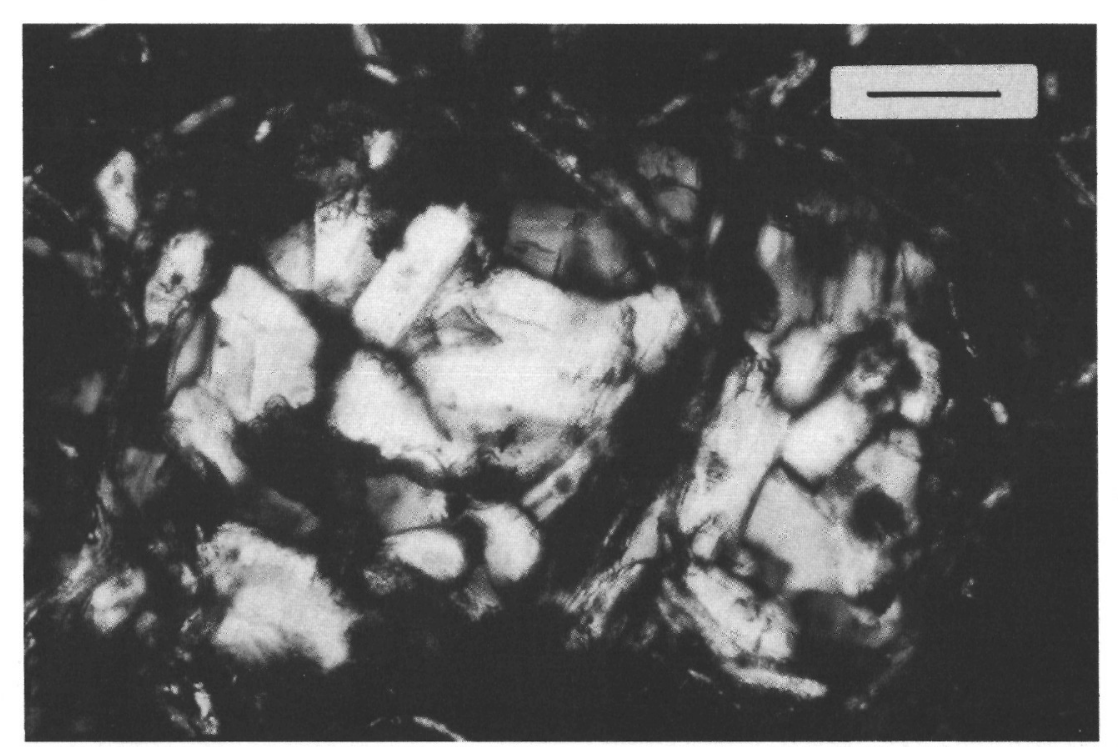

Figure 43. Photomicrograph of Sample 45-1(140-142). Vesicles, filled with prismatic clinoptilolite crystals. Crossed polarizers. Length of scale bar is $60 \mu$.

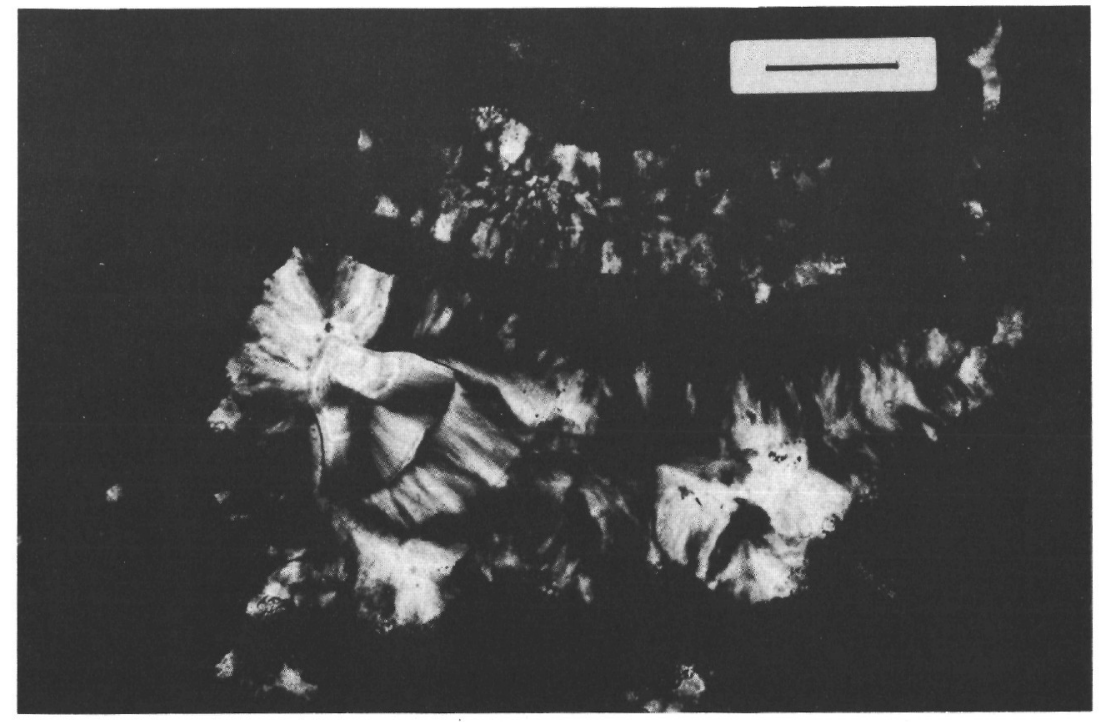

Figure 42. Same view as in Figure 41. Crossed polarizers. Length of scale bar is $100 \mu$.

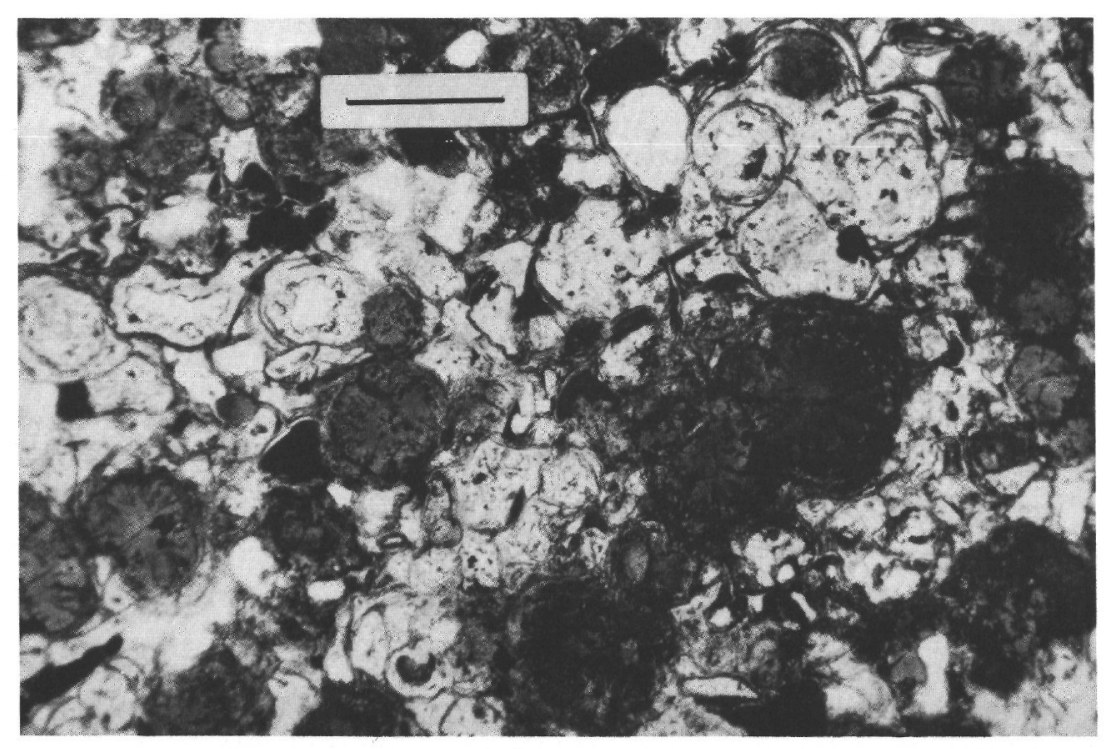

Figure 44. Photomicrograph of Sample 45-1(140-142). Spherulites in a zeolitized (clinoptilolite) groundmass. Plane polarized light. Length of scale bar is $500 \mu$. 


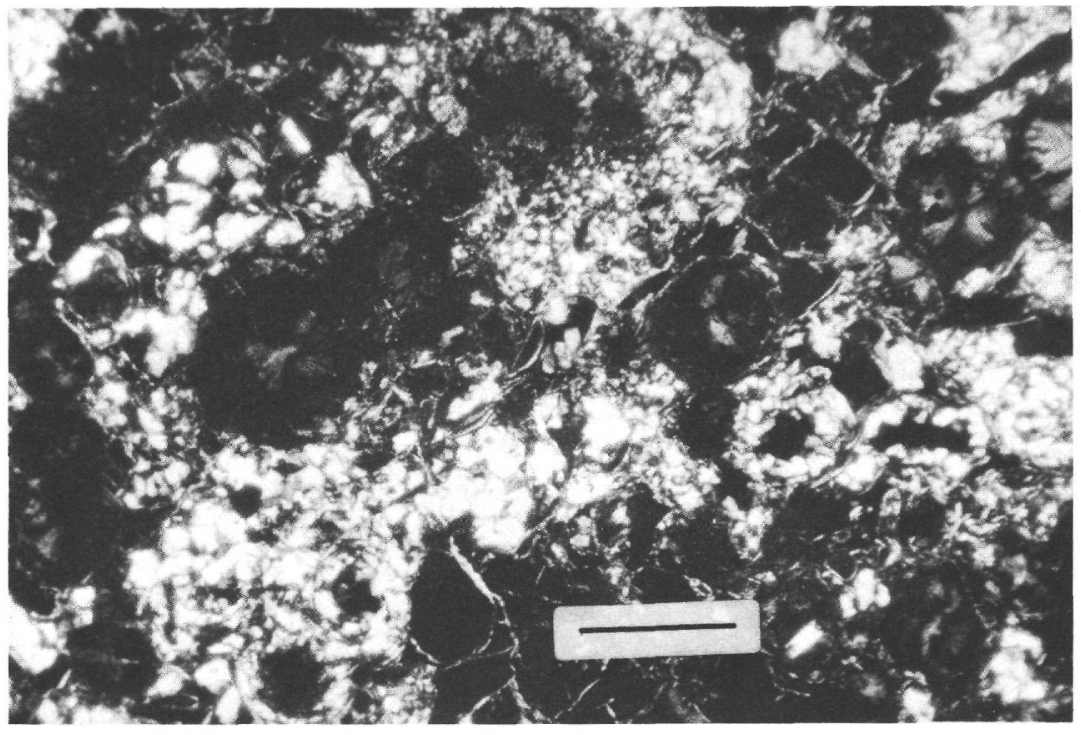

Figure 45. Same view as in Figure 44. Crossed polarizers. Length of scale bar is $500 \mu$.

for example, and intrusion into wet sediments can also produce hyaloclastites (Parsons, 1969). Finally, it should be noted that no sediments have been observed intercalated within the volcanics. Such sediments might have provided a more definite answer to our problem.

In conclusion, it can be stated that the Lord Howe Rise rhyolites do not display unequivocal characteristics from which a subaerial or subaqueous extrusive origin can be concluded. The pumiceous lapilli tuffs in Unit 4 provide the best evidence for suggesting that at least part of the rocks in that unit are of subaerial or very shallow marine origin.

\section{AGE OF THE ROCKS}

Three samples from Unit 4, 207A-34(CC), 207A35-3(30-90) and 207A-39(CC), were used for radiometric dating by Dr. I. McDougall, Australian National University Canberra. The potassium-argon ages are very concordant and give a mean age of $93.7 \pm 1.2 \mathrm{~m} . \mathrm{y}$.

These Upper Cretaceous ages fit in well with the overall stratigraphy at Site 207. Unit 3, a silty claystone overlying the volcanics, was dated Maestrichtian from sparse arenaceous foraminifers (See Peter Webb, this volume). At the base of this unit, coarser-grained sediment immediately overlies the volcanics and contains reworked rhyolitic material, together with material from other sources.

\section{NOTE ON ARGILLIZATION}

\section{(W. A. Watters)}

Widespread argillization similar to that found in the sequence examined could be expected in certain circumstances from deep subaerial weathering. Montmorillonite, for example, is a common superficial weathering mineral on volcanic rocks in temperate regions such as the North Island of New Zealand. On the other hand, the pervasive nature of the clay in many of the Lord Howe Rise rocks, and particularly the presence of other secondary minerals such as zeolite, chalcedony, and opal, suggest that the argillization is the result of hydrothermal alteration during the dying phases of volcanic activity. At Wairakei geothermal district, New Zealand, Steiner (1968, p. 207) has shown that the montmorillonite widespread there has generally formed at temperatures up to $130^{\circ} \mathrm{C}$ and, in any case, not more than $160^{\circ} \mathrm{C}$. It is found at shallow depths, between 100 feet and 700 feet below the surface, where it replaces both plagioclase and glassy groundmass or matrix of massive volcanic and fragmental rocks. With increasing temperature of alteration at Wairakei, and also at the nearby Broadlands field (Browne and Ellis, 1970), montmorillonite is replaced by interlayered oorillonite, morillonite, which in turn is replaced by illite. Halloysite is not found at Wairakei but the related mineral kaolinite forms near the surface in acid environments, at temperatures below $60^{\circ} \mathrm{C}$. At Broadlands, however, minor halloysite has been found (personal communication, P.R.L. Browne).

\section{ACKNOWLEDGMENTS}

The author is grateful to Dr. W.A. Watters, Chief Petrologist of the New Zealand Geological Survey (NZGS), for assistance in many phases of the preparation of this paper, from commenting on thin sections and organizing instrument analyses to critically reading the final manuscript. He offered many suggestions for its improvement and kindly provided the "Note on Argillization".

Dr. I. McDougall of the Institute of Advanced Studies, the Australian National University, Canberra, was able to obtain radiometric dates for the rhyolites at Site 207 from the limited amount of sample available to him. We are grateful for his efforts.

Instrument analyses were carried out by Messrs. J. Olivecrona, R. Soong (Both of the NZGS), and J.M.G. Shelley (Geology Department, University of Canterbury). The photographys were printed by Messrs. G.W. Richards (NZGS) and A.L. Smith (Geol. Dept., U. of C.). Mr. D.J. Jones (Geol. Dept., U. of C.) made some of the thin sections. The author benefitted from discussions with $\mathrm{Dr}$. 
D. Shelley (Geol. Dept., U. of C.) and Mr. P.R.L. Browne (NZGS). Miss C.M. Johnstone (NZGS) patiently typed out the various drafts of the paper.

\section{REFERENCES}

Anderson, J.E., 1969. Development of snowflake texture in a welded tuff. Bull. Geol. Soc. Am. 80 (10), 2075.

Boyd, F.R., 1961. 'Welded tuffs and flows in the rhyolite plateau of Yellowstone Park, Wyoming. Bull. Geol. Soc. Am. 72 (3), 387.

Browne, P.R.L. and Ellis, A.J., 1970. The Ohaki-Broadlands hydrothermal area, New Zealand: mineralogy and related geochemistry. Am. J. Sci. 269, 97.

Ewart, A., 1963. Petrology and petrogenesis of the Quarternary pumice ash in the Taupo area, New Zealand. J. Petrol. 4 ( 3), 392.

1965. Mineralogy and petrogenesis of the Whakamaru ignimbrite in the Maraetai area of the Taupo Volcanic Zone, New Zealand. N.Z. J. Geol. Geophys. 8 (4), 611 .

1971. Chemical changes accompanying spherulitic crystallization in rhyolitic lavas, Central Volcanic Region, New Zealand. Min. Mag. 38 (296), 424.

Fisher, R.V., 1966. Rocks composed of volcanic fragments and their classification. Earth Sc. Rev. 1 (4), 287.
Fiske, R.S., 1963. Subaqueous pyroclastic flows in the Ohanapecosh Formation, Washington. Bull. Geol. Soc. Am. 74 (4), 391.

Johannsen, A., 1939. A descriptive petrography of the igneous rocks, Vol. I. Univ. Chicago Press, 318 p.

Lofgren, G., 1971. Experimentally produced devitrification textures in natural rhyolitic glass. Bull. Geol. Soc. Am. $82(1), 111$.

McBirney, A.R., 1963. Factors governing the nature of submarine volcanism. Bull. Volcanol. XXVI, 455.

Nayudu, Y.R., 1962. Submarine eruptions of basalts and the problems of palagonitization (abstract). Intern. Symp. on Volc., Japan, 49.

Parsons, W.H., 1969. Criteria for the recognition of volcanic breccias: review. In Igneous and metamorphic geology. Larson, L. et al. Geol. Soc. Am. Mem. 115. 263.

Ross, C.S., and Smith, R.L., 1961. Ash-flow tuffs: their origin, geologic relations, and identification. U.S. Geol. Survey Prof. Paper 366, 81 p.

Steiner, A., 1960. Origin of ignimbrites of the North Island, New Zealand: a new petrogenetic concept. Bull. N.Z. Geol. Survey n.s. 68, 42 p.

1968. Clay minerals in hydrothermally altered rocks at Wairakei, New Zealand. Clays and Clay Minerals $16,193$.

Vance, J.A., 1969. On synneusis. Contr. Min. Petrol. 24, 7. 